\title{
Holocene relative sea-level changes in the Qaqortoq area, southern Greenland
}

\author{
CHARLOTTE J. SPARRENBOM, OLE BENNIKE, SVANTE BJÖRCK AND KURT LAMBECK
}

\section{BOREAS}

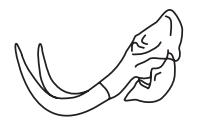

\begin{abstract}
Sparrenbom, C. J., Bennike, O., Björck, S. \& Lambeck, K. 2006 (May): Holocene relative sea-level changes in the Qaqortoq area, southern Greenland. Boreas, Vol. 35, pp. 171-187. Oslo. ISSN 0300-9483.

We present results from an investigation of relative sea-level changes in the Qaqortoq area in south Greenland from c. $11000 \mathrm{cal}$. yr BP to the present. Isolation and transgression sequences from six lakes and two tidal basins have been identified using stratigraphical analyses, magnetic susceptibility, XRF and macrofossil analyses. Macrofossils and bulk sediments have been dated by AMS radiocarbon dating. Maximum and minimum altitudes for relative sea level are provided from two deglaciation and marine lagoon sequences. Initially, relative sea level fell rapidly and reached present-day level at $\sim 9000$ cal. yr BP and continued falling until at least 8800 cal. yr BP. Between 8000 and $6000 \mathrm{cal}$. yr BP, sea level reached its lowest level of around 6-8 m below highest astronomical tide (h.a.t.). At around $3750 \mathrm{cal}$. yr BP, sea level has reached above $2.7 \mathrm{~m}$ below h.a.t. and continued to rise slowly, reaching the present-day level between $\sim 2000$ cal. yr BP and the present. As in the Nanortalik area further south, initial isostatic rebound caused rapid isolation of low elevation basins in the Qaqortoq area. Distinct isolation contacts in the sediments are observed. The late Holocene transgression is less well defined and occurred over a longer time interval. The late Holocene sea-level rise implies reloading by advancing glaciers superimposed on the isostatic signal from the North American Ice Sheet. One consequence of this transgression is that settlements of Palaeo-Eskimo cultures from $\sim 4000$ cal. yr BP may have been transgressed by the sea.
\end{abstract}

Charlotte J. Sparrenbom (e-mail: charlottesparrenbom@geol.lu.se), Centre for GeoBiosphere Science, Quaternary Geology, Lund University, Sölvegatan 12, SE-22362 Lund, Sweden; Ole Bennike (e-mail: obe@geus.dk), Geological Survey of Denmark and Greenland, Øster Voldgade 10, DK-1350 Kobenhavn, Denmark; Svante Björck (e-mail: svante.bjorck@geol.lu.se), Centre for GeoBiosphere Science, Quaternary Geology, Lund University, Sölvegatan 12, SE-223 62 Lund, Sweden; Kurt Lambeck (e-mail: Kurt.Lambeck@anu.edu.au), Research School of Earth Sciences, Australian National University, Canberra, ACT 0200 Australia; received 25th July 2005, accepted 25th October 2005.

Observations of relative sea-level change through time provide constraints on volumes of past ice sheets as well as their retreat history. Data from localities around the world have been used to constrain the ice volumes of individual ice sheets as well as the total change in ice volume for the Last Glacial Maximum and later times (Lambeck \& Chappell 2001). The Greenland Ice Sheet is one of the ice sheets investigated in this way (Fleming \& Lambeck 2004) and is also the one addressed here. Holocene relative sea-level changes around Greenland have been observed and reported earlier in a number of investigations from different sites (e.g. Funder 1978; Björck \& Persson 1981; Björck et al. 1994; Rasch et al. 1997; Rasch \& Jensen 1997; Kelly et al. 1999; Long et al. 1999; Rasch 2000; Bennike \& Weidick 2001; Long \& Roberts 2002; Long et al. 2003). Only limited data have been available from southern Greenland (Fredskild 1973; Funder 1979; Bennike et al. 2002; Weidick et al. 2004). Sparrenbom et al. (2006) recently presented a continuation of the investigation by Bennike et al. (2002), but data from other localities are needed to facilitate understanding of the spatial variability of postglacial sealevel changes and to constrain the associated isostatic rebound.
In this article, we present a shoreline displacement study from the Qaqortoq-Narsarsuaq area based on three sites situated below present highest astronomical tide (b.h.a.t.) and seven sites situated above highest astronomical tide (a.h.a.t.). The shoreline displacement observations extend from $31 \mathrm{~m}$ a.h.a.t at $c .11000 \mathrm{cal}$. yr BP down to around $6-8 \mathrm{~m}$ b.h.a.t. at $c$. $6000-8000$ cal. yr BP and reached present sea level between $c .2000$ $\mathrm{BP}$ and the present. This is the second part of an investigation aiming to elucidate the relative sea-level history of the southern Greenland sector. The first part included a shoreline displacement curve from c. 15000 cal. yr BP to the present from the Nanortalik area (Bennike et al. 2002; Sparrenbom et al. 2006).

Earlier evidence for late Holocene relative sea-level changes in this part of southern Greenland comes mostly from marine geological and archaeological studies. It includes: (i) a sub-aerially weathered 'dry crust' found at c. $9.3-10 \mathrm{~m}$ below present sea level (b.s.1.) in a core taken in Narsaq harbour dated to $>2800$ cal. yr BP (Bennike et al. 2002; Weidick et al. 2004), (ii) an un-dated drowned beach at 3-4 m b.s.l. situated close to the Norse settlement at Qassiarsuk (Brattahlid) (Kuijpers et al. 1999), and (iii) Norse and Neo-Eskimo ruins situated close to the present 
spring tide water level (Mathiassen 1936; Bak 1969). Gabel-Jørgensen \& Egedal (1940) performed tidal measurements between 1883 and 1885, and again from 1932 to 1934, and reported sinking of the land in southern Greenland at a rate of $3.9 \pm 0.38 \mathrm{~mm}$ per year in the interval between the two measurements.

\section{Field area}

The investigation is performed in South Greenland (Fig. 1) in a barren, glacially abraded fjord landscape dominated by rounded and flattened mountains reaching a maximum elevation of $500 \mathrm{~m}$ a.s.l near the coast. Further inland the alpine mountains reach up to $1500 \mathrm{~m}$ a.s.l. The glacially eroded and over-deepened fjords reach depths greater than $600 \mathrm{~m}$. The ice-free land area is around $100 \mathrm{~km}$ wide and the offshore shelf is relatively narrow, about $70 \mathrm{~km}$ wide. The regional bedrock consists of Precambrian granites, sandstones and different intrusions of syenites and magmatic rock types.

The present-day mean annual temperature at Qaqortoq is $4^{\circ} \mathrm{C}$, whereas the mean temperature during the coldest month (January) is $-5.5^{\circ} \mathrm{C}$ and the mean temperature during the warmest months is $7^{\circ} \mathrm{C}$ (July and August). Further inland, towards Narsarsuaq, the temperatures are higher during summer, with mean temperatures of over $10^{\circ} \mathrm{C}$ during the warmest month (July), while the winter mean temperature is $-7^{\circ} \mathrm{C}$ during the coldest month (January). The precipitation varies from $860 \mathrm{~mm}$ per year at the outer coast to 600 $\mathrm{mm}$ per year at Narsarsuaq near the inland ice margin. 'Storisen', a wide zone of drift ice following the East Greenland Current, reaches the area in late winter and disappears during the summer. At the outer coast, cool, cloudy and foggy conditions are common during summer months, caused by the meeting of the cold East Greenland Current and the warmer Irminger Current. Dwarf-shrub heaths with mosses and lichens dominate the vegetation. Empetrum sp., Betula glandulosa and Salix glauca constitute major elements in the heaths. Betula pubescens and Salix glauca occur in protected lowland areas.

\section{Methods}

The bathymetry of the basins was investigated with an echo-sounder in order to find suitable coring sites and the coring positions were determined with GPS. A specially designed Zodiac, with a funnel-hole in the centre, was used as a tethered coring platform. Using a Russian corer, multiple overlapping core sediment sequences were collected from the different basins.

Since the aim of the investigation is to re-establish relative sea level, it is important to take tides into consideration. The h.a.t. is of importance because it controls when marine water first enters a basin during

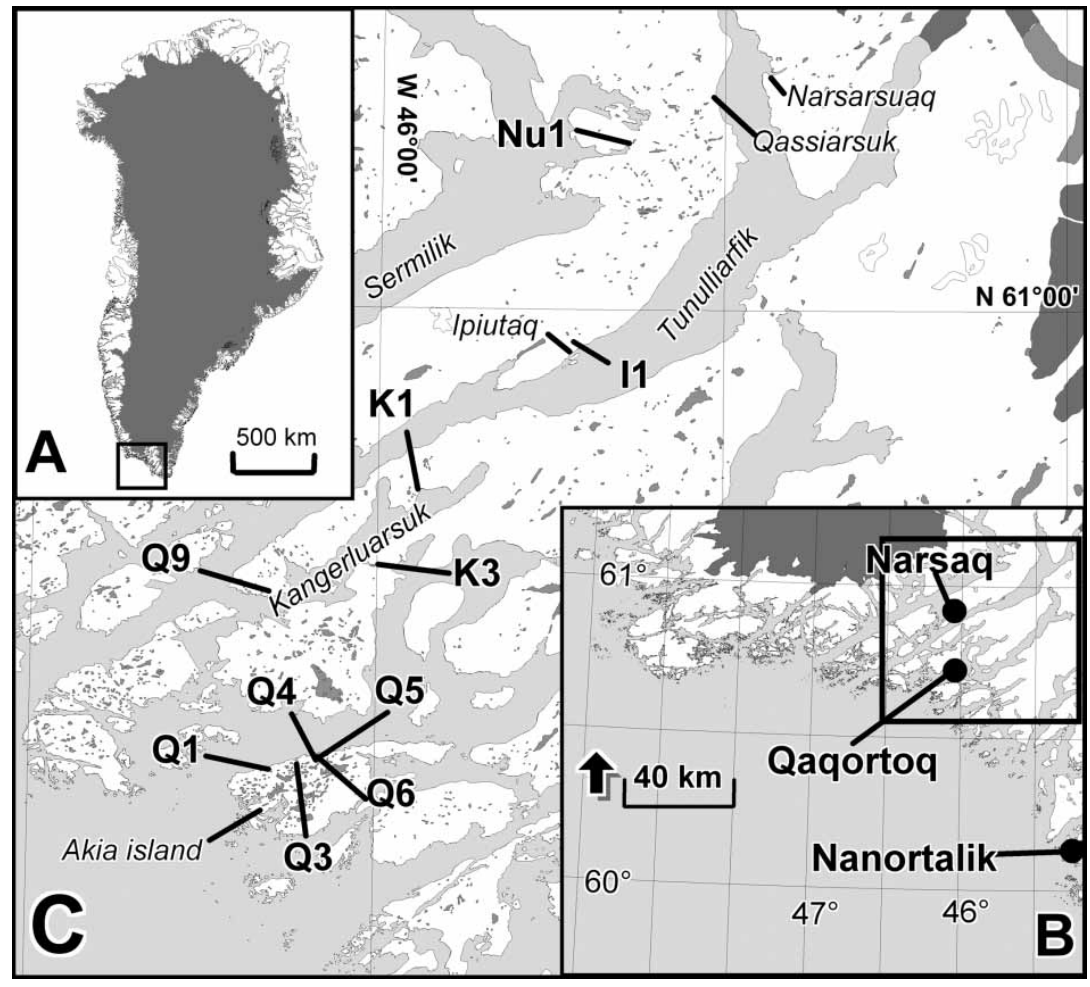

Fig. 1. A. Map of Greenland. The rectangle marks the sector where the investigated sites are located. B. Map of the southern Greenland sector. The rectangle defines the field area. C. Map showing the locations of investigated sites. 
Table 1. Estimates of total uncertainty for each investigated site. Clinometer method uncertainty: $\pm 10 \mathrm{~cm}$ per measured eye-height of the measuring person; rod measurements uncertainty: $\pm 10 \mathrm{~cm}$ per measurement; measurements done photogrammetrically: $\pm 100 \mathrm{~cm}$ per measurement.

\begin{tabular}{|c|c|c|c|c|c|c|}
\hline Site & $\begin{array}{l}\text { Measured } \\
\text { height } \mathrm{m} \\
\text { a.m.s.l. }\end{array}$ & $\begin{array}{l}\text { Measurement } \\
\text { method }\end{array}$ & $\begin{array}{l}\text { Measurement } \\
\text { uncertainty } \\
\text { (m) }\end{array}$ & $\begin{array}{l}\text { Assessment of } \\
\text { threshold uncertainty } \\
\text { (m) }\end{array}$ & $\begin{array}{l}\text { Tidal } \\
\text { uncertainty } \\
\text { (m) }\end{array}$ & $\begin{array}{l}\text { Total } \\
\text { uncertainty } \\
\text { (m) }\end{array}$ \\
\hline Q1 & 0.7 & Rods & \pm 0.1 & 0 & \pm 0.5 & \pm 0.5 \\
\hline Q3 & -1.0 & Rods & \pm 0.1 & 0 & \pm 0.5 & \pm 0.5 \\
\hline Q4 & 14 & Clinometer & \pm 0.3 & \pm 0.1 & \pm 0.5 & \pm 0.6 \\
\hline Q5 & 24 & Clinometer & \pm 0.4 & \pm 0.3 & \pm 0.5 & \pm 0.7 \\
\hline Q6 & -6.8 & Rods & \pm 0.1 & \pm 1 & \pm 0.5 & \pm 1.1 \\
\hline Q9 & 32.7 & Clinometer & \pm 0.5 & \pm 0.1 & \pm 0.5 & \pm 0.7 \\
\hline $\mathrm{K} 1$ & 5.6 & Clinometer & \pm 0.2 & 0 & +0.5 & \pm 0.5 \\
\hline K3 & 8.9 & Clinometer & \pm 0.24 & \pm 0.25 & \pm 0.5 & \pm 0.6 \\
\hline I1 & 41.3 & Photogrammetrically & \pm 1 & 0 & \pm 1.5 & \pm 1.8 \\
\hline $\mathrm{Nu} 1$ & 11.4 & Clinometer/ Photogrammetrically & \pm 0.3 & 0 & \pm 0.5 & \pm 0.6 \\
\hline
\end{tabular}

transgression or when marine water influence ceases during regression. Storm events can cause marine water to enter an otherwise isolated basin, but estimates are uncertain as the effect depends on basin exposure, topography, fetch, storm frequency and rate of shoreline displacement in the area. The h.a.t. has been calculated using the global tidal model AG (Andersen Grenoble 1995.1) by O. Andersen at the Danish National Survey and Cadastre in Copenhagen and varies between sites from $c .1 .74$ to $1.76 \mathrm{~m}$ above mean sea level. The tidal range for the area is $c .3 .3 \mathrm{~m}$ at spring tide (Farvandsvæsenet 2000, 2001).

The elevations of the sills of the lakes were measured with a clinometer in the field and photogrammetrically, using a Digital Photogrammetric Workstation with Socet Set software (BAE Systems), in the laboratory of the Geological Survey of Denmark and Greenland. The levels of the thresholds of the shallow marine basins were measured using an echo-sounder and measurement rods. Estimates of the accuracy of these measurements are included in Table 1. By noting the time of measurement, tidal corrections were possible. The total uncertainty estimate at each site depends on the accuracy of the measurement, the interpreted threshold development and the uncertainty in tidal range and time, and the total uncertainty (the standard deviation) is $\sigma_{\text {total }}=\left(\sigma_{1}^{2}+\sigma_{2}^{2}+\sigma_{3}^{2}\right)^{1 / 2}$, where $\sigma_{1}$ is the uncertainty of the measurement, $\sigma_{2}$ is the uncertainty of the threshold development and $\sigma_{3}$ is the uncertainty of the tidal span and time. The total uncertainty estimate at each site is given in Table 1.

Detailed lithological descriptions were carried out in the laboratory before subsampling for macrofossil analyses and radiocarbon dating. To facilitate core correlations, all cores were scanned using a Bartington MS2E high-resolution sensor controlled by a Tamiscan automated stage measuring the magnetic susceptibility every $4 \mathrm{~mm}$. The magnetic susceptibility $\left(10^{-6} \mathrm{~m}^{3}\right.$ $\mathrm{kg}^{-1}$ ) depends on the amount and physical properties of the magnetic material present in the sample.
X-ray fluorescence core scanning (XRF) was carried out at the Research Center Ocean Margins, Bremen, on selected cores to complement the other analyses in the identification of isolation and transgression sequences. The XRF core scanner is a non-destructive analysis system for scanning flat surfaces of sedimentary archives. The cores were measured in the XRF scanner (Cortex, AVAATECH; see Jansen et al. 1998) in closely spaced steps, the step sizes being pre-programmed in varying lengths depending on lithological changes. The following 13 elements were measured: potassium, calcium, iron, manganese, zinc, lead, copper, cobalt, nickel, titanium, strontium, chromium and vanadinium, although five of the elements, lead, zinc, chromium, vanadinium and nickel, were present in too low quantities and have not been considered further. Röhl \& Abrams (2000) describe the use of the XRF methodology as a quick and inexpensive way to identify sedimentological and environmental changes. The method has previously been used for marine cores (Lamy et al. 2001) and for lake sediments (Daryin et al. 2005).

The chemistry of sediments depends on the nature of material available, the depositional environment and the changes the sediments undergo through time. Most of the elements measured exist in higher concentrations in marine environments than in freshwater environments. Copper, however, tends to bind with organic matter, and as the amount of organic matter deposited in freshwater environments, in general, is higher than in marine environments, copper will generally occur in higher concentrations in freshwater sediments.

Samples were wet sieved for macrofossil analysis using a $0.2-\mathrm{mm}$ sieve and the plant and animal macrofossils were used to verify the interpretations of environmental changes, i.e. isolations/transgressions. AMS radiocarbon dating was then carried out on selected fossils or on bulk sediment samples where suitable macrofossils were not available. The radiocarbon dates were calibrated using the software OxCal v.3.10, based 


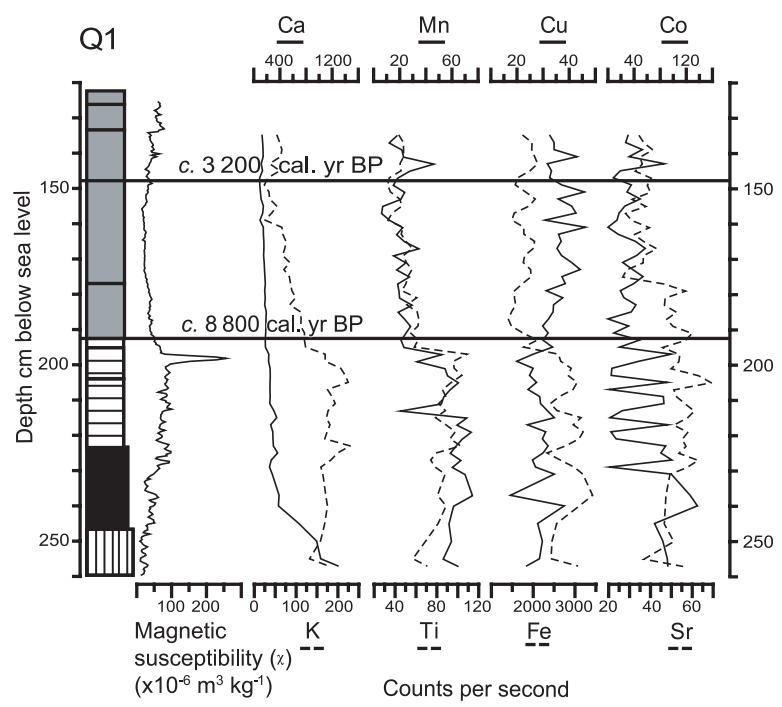

Sandy silty detritus gyttja

Silty sand with various contents of gravel Sandy gyttja silt

A IIII Sandy gyttja silt to silty gyttja sand

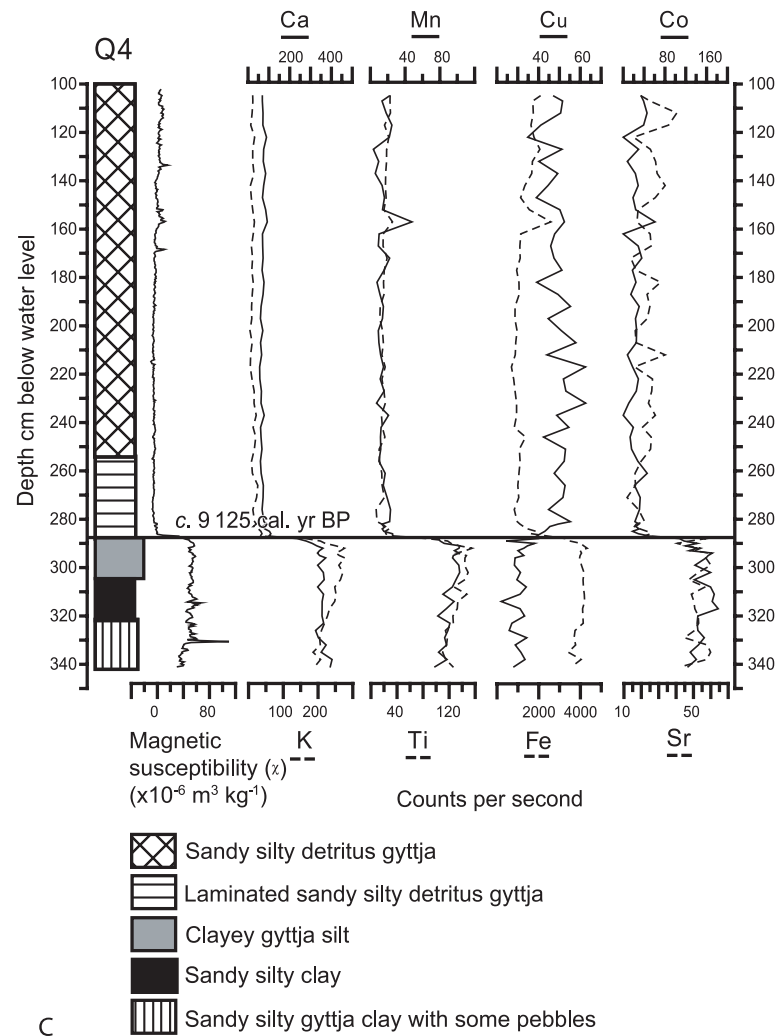

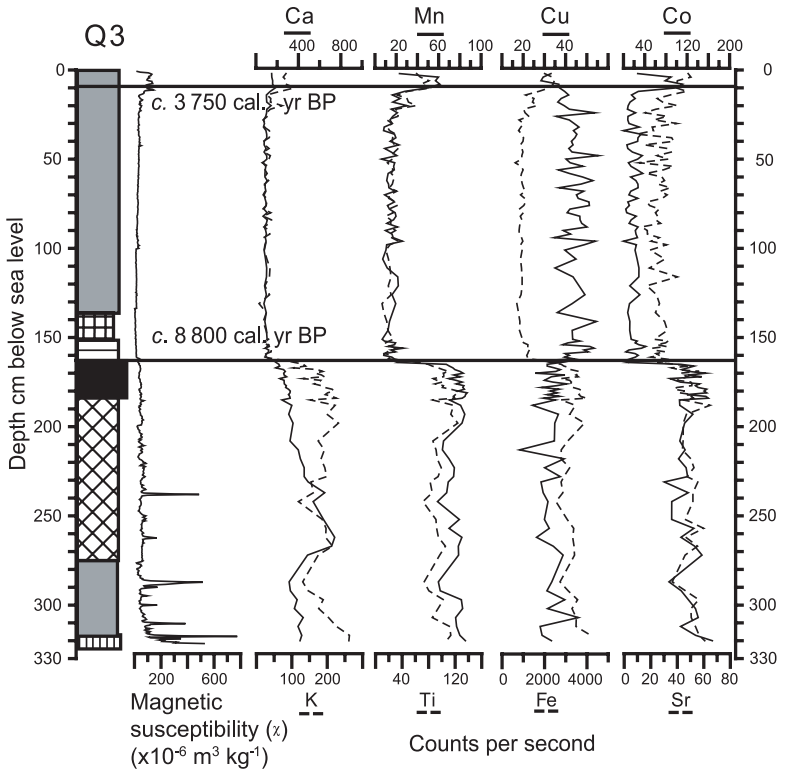

Detritus gyttja
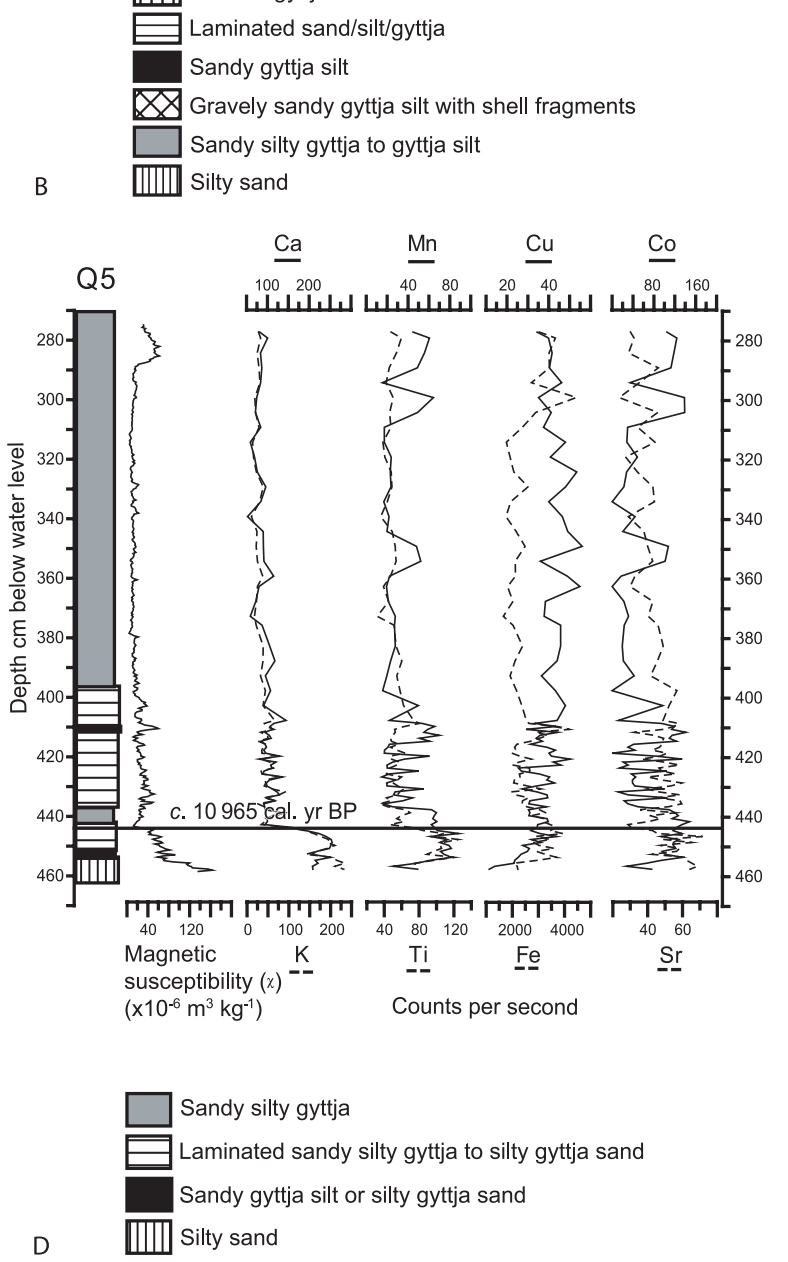

Fig. 2. Simplified core log, magnetic susceptibility and XRF-measured elements for (A) site Q1, (B) site Q3, (C) site Q4, (D) site Q5, (E) site Q6, (F) site Q9, (G) site K1, (H) site K3, (I) site I1, (J) site Nu1. Note the different scales for the different elements. 


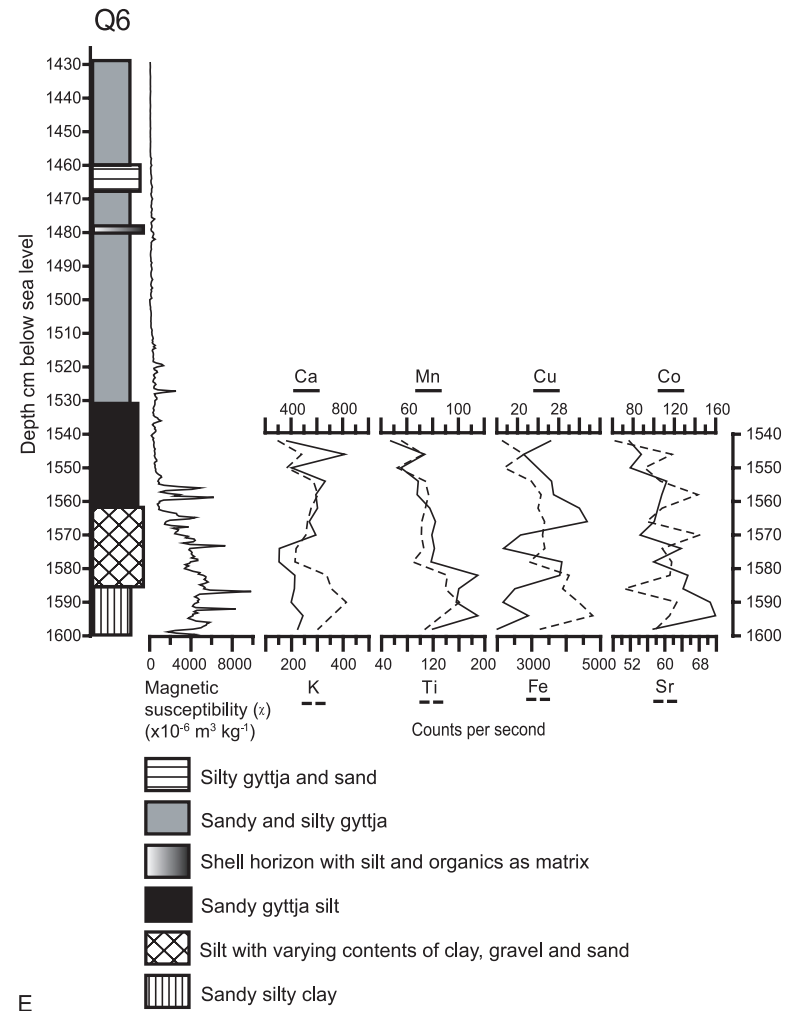

E

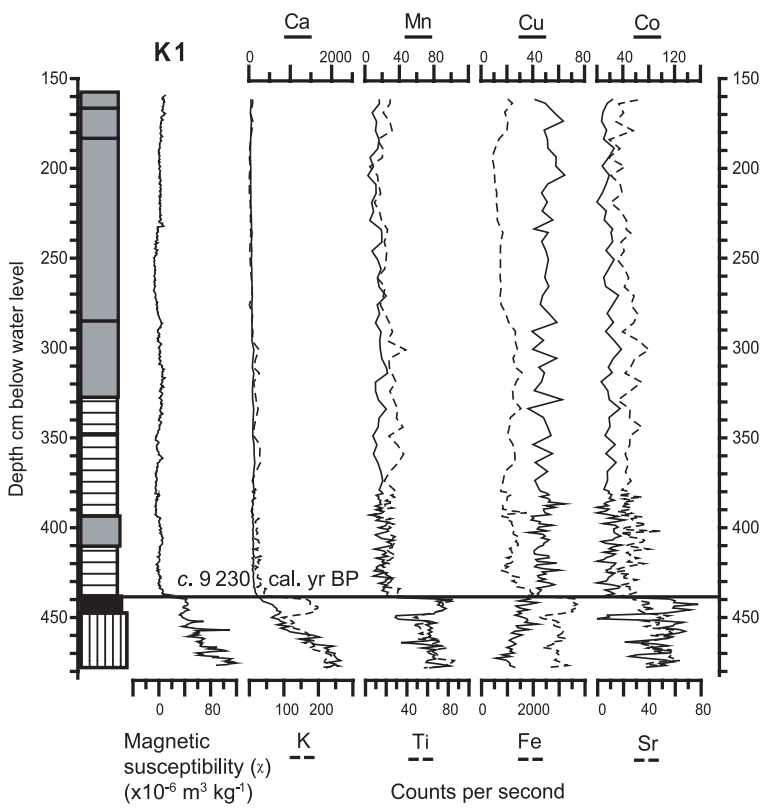

Sandy silty detritus gyttja

Laminated sandy silty gyttja

Sandy gyttja silt

G $\quad$ WाI Sandy gyttja silt to silty gyttja sand
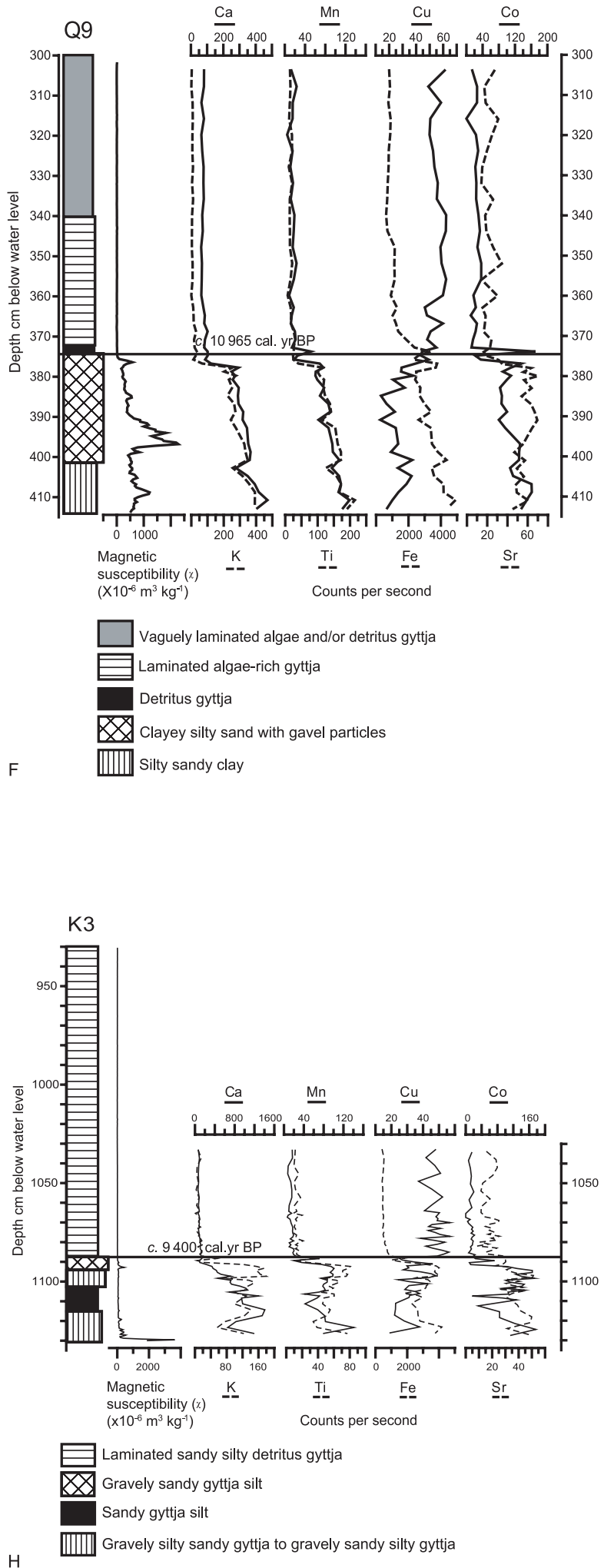

Fig. 2 (Continued) 


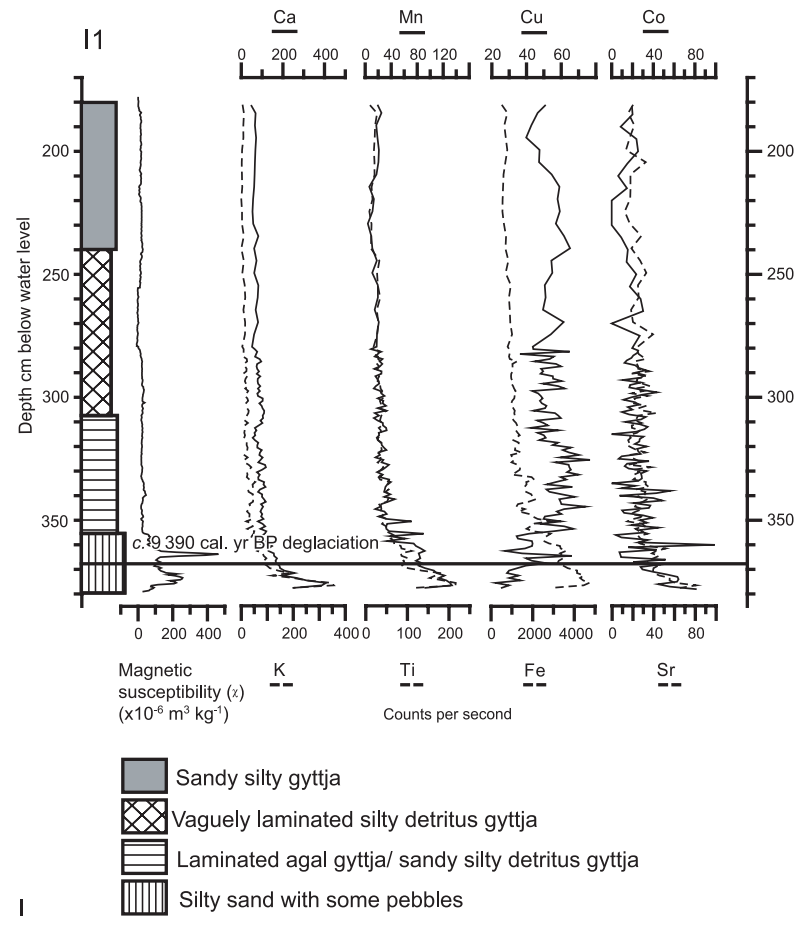

Fig. 2 (Continued)

on the terrestrial INTCAL04 data set of Reimer et al. (2004). The radiocarbon analyses provide ages for the time of isolation and transgression of each basin.

\section{Results}

Out of the 10 investigated sites, 5 are located in close vicinity to Qaqortoq on the island of Akia, and 5 sites are located further inland within the Kangerluarsuk, Tunulliarfik and Sermilik fjords. We use codes for the sites based on geographical names of the local areas where Q stands for Qaqortoq, K for Kangerluarsuk, I for Ipiutaq and $\mathrm{Nu}$ for Nunataaq. Sediment depths in the descriptions refer to depth below water surface. Altitudes of the thresholds are related to metres above $(+)$ or below $(-)$ highest astronomical tide ( $\mathrm{m}$ a.h.a.t. and $\mathrm{m}$ b.h.a.t., respectively). Positions and sill altitudes are indicated in the heading of each site.

Tidal basin $Q 1\left(N 60^{\circ} 40.264^{\prime}, W 46^{\circ} 08.921^{\prime}\right),-1.0 \mathrm{~m}$

The site, located on the island of Akia (Fig. 1), is a marine tidal basin with a threshold consisting of bedrock and larger boulders at $-1.0 \mathrm{~m}$ b.h.a.t. The basin is circular in shape, $c .100 \mathrm{~m}$ in diameter, and lakes higher up in the terrain drain into it. Its threshold is directed towards the WNW and is exposed to waves because of its location close to the fjord

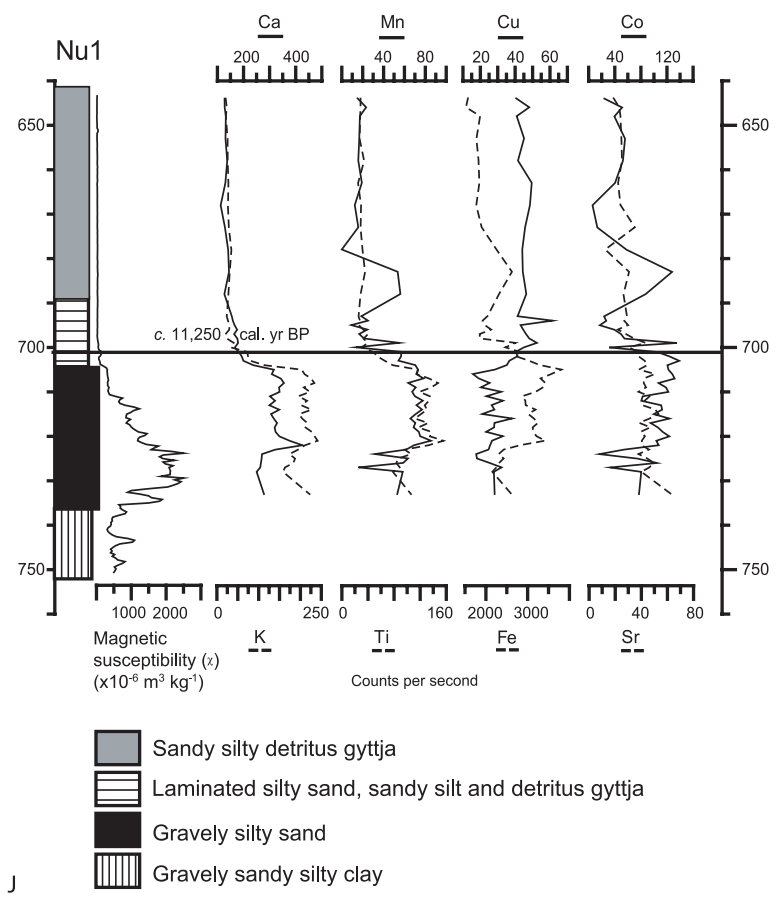

mouth. The basin is shallow with a maximum water depth of $1.4 \mathrm{~m}$ and $1.3 \mathrm{~m}$ at the coring site. At the isolation contact at $191.5 \mathrm{~cm}$, the sediments change sharply from silty sand with visible macrofossils to silty sandy detritus gyttja (Fig. 2A). The bivalve Mytilus edulis and cocoons from marine flatworms Tricladida decrease above this level and disappear totally higher up in the stratigraphy. At $c .191 .5 \mathrm{~cm}$ the freshwater fossils Cladocera, Isoëtes sp., Batrachium confervoides and Chironomidae increase in numbers and start to dominate (Fig. 3A). The magnetic susceptibility increases from the bottom of the sediment column and peaks just before $191.5 \mathrm{~cm}$, where the susceptibility shows a marked decrease. The XRF results also show marked changes at $c .191 .5 \mathrm{~cm}$, especially titanium and iron values falling abruptly at this level (Fig. 2A). The age of the isolation of the basin is determined to around 8800 cal. yr BP based on three macrofossil samples; one at and below the isolation contact containing Empetrum sp., Potamogeton sp., Bryopsida indet., Carex sp., unidentified leaf fragments and Batrachium confervoides (86009000 cal. yr BP); one from just above the isolation containing Empetrum sp., Hippuris vulgaris, Carex sp., Potamogeton sp., Batrachium confervoides (84509000 cal. yr BP); and one gyttja bulk sediment sample taken above the isolation contact $(8340-8550$ cal. yr BP) (Table 2).

The transgression event is harder to establish from the lithological analyses alone, as there is no visibly 
distinct sedimentary change. In particular, there is no distinct hiatus, implying a total lack of sediment during any time period, but the sediment sequence appears to be short with $c$. $60 \mathrm{~cm}$ deposited in 8800 years. The magnetic susceptibility, as well as the XRF curves, indicates changes at the following levels: $156 \mathrm{~cm}$, $145 \mathrm{~cm}, 142 \mathrm{~cm}$ and $134 \mathrm{~cm}$ (Fig. 2A). A few marine macrofossils are found in the sediment sequence already at $150 \mathrm{~cm}$ and $153 \mathrm{~cm}$, and these may be the result of transport during stormy conditions when the threshold level is close to the highest tide, consistent with its open exposure. At $147 \mathrm{~cm}$ the number of marine specimens and the number of marine taxa increase, but freshwater taxa like Hippuris vulgaris, Isoëtes sp. and Potamogeton sp. are still present in the basin. The presence of both marine and lacustrine species in the basin, deposited at the same time during a longer time-span, indicates a gradual transgressional process. It is possible, however, that erosion and redeposition occurred that resulted in a mixture of new and older material, as is indicated by the four radiocarbon analyses from levels $127.5-138 \mathrm{~cm}$ (macrofossils), $137-138 \mathrm{~cm}$ (gyttja), 138-142 cm (macrofossils) and $142-143 \mathrm{~cm}$ (gyttja), with the macrofossils of terrestrial or freshwater origin being younger than the bulk samples. From macrofossil analysis, the transgression is placed at $c .147 \mathrm{~cm}$ and a radiocarbon date from a bulk sediment sample at $142-143 \mathrm{~cm}$ suggests a minimum age of $c$. 3200 cal. yr BP $(2870-3170$ cal. yr BP) (Table 2). This also indicates a slow late Holocene sea-level rise, as this basin is isolated during low tide today.

Tidal basin $Q 3\left(N 60^{\circ} 40.550^{\prime}, W 46^{\circ} 06.638^{\prime}\right),-2.7 m$

The site is a marine tidal basin on the island of Akia (Fig. 1) with a threshold consisting of bedrock. It is oval in shape, $c .400 \times 100 \mathrm{~m}$ in size, and is fed by water from lakes higher up in the terrain. The threshold is directed towards the ENE and sheltered because the bay entrance leading into the basin is directed towards the NW. The basin is shallow with a maximum water depth of $3.5 \mathrm{~m}$ and the depth at the coring site varied between 2.0 and $3.45 \mathrm{~m}$ as a consequence of the changing tides and shifting positions of the coring platform. The cores could, however, be successfully correlated visually and/or with magnetic susceptibility and XRF scans. The isolation contact is placed at $162 \mathrm{~cm}$ at the transition from laminated sand, silt and gyttja into vaguely laminated algal gyttja (Fig. 2B). Marine brown algae and Mytilus edulis disappear above this level and freshwater fossils Cladocera, Chironomidae and Isoëtes sp. start to dominate (Fig. 3B). Magnetic susceptibility (Fig. 2B) shows only a small decrease at the level of the isolation, while most of the elements measured by the XRF scanner show marked changes. Potassium, titanium, manganese, iron and strontium show strong decreases at around $162 \mathrm{~cm}$, while the copper counts increase.

The transgression phase can be seen in the sediments as a transition from sandy silty detritus gyttja with visible macrofossils, changing into sandy silty gyttja containing gravel particles. Marine brown algae, Hydroidea and Tricladida appear at about $8 \mathrm{~cm}$ depth in the sediments and soon after Mytilus edulis appears and a marine fauna and flora expands while the number of freshwater plants and animals such as Cladocera, Chironomidae and Isoëtes sp. decreases (Fig. 3B). The magnetic susceptibility values start to increase at $c .15 \mathrm{~cm}$ level, peaking at 11,8 and $4 \mathrm{~cm}$. The XRF measurements show changes beginning at $c$. $20 \mathrm{~cm}$ level with fluctuating but increasing values for all elements except copper, which decreases. The largest changes in XRF values appear at $10 \mathrm{~cm}$ level peaking at $c .5 \mathrm{~cm}$.

The isolation of the basin is dated to $c .8800 \mathrm{cal}$. $\mathrm{yr}$ BP (Table 2) based on two samples. The first is a macrofossil sample from the isolation $(160-165 \mathrm{~cm}$ level) containing Potamogeton sp., Bryopsida indet., Empetrum sp., Juniperus sp., leaf fragment, Salix herbacea, Hippuris vulgaris, Carex sp., Isoëtes sp., Chironomidae adult, Daphnia sp. and Plumatella repens (8600-9000 cal. yr BP). The second is a bulk sediment sample taken above the isolation at $161.0-161.8 \mathrm{~cm}$ level $(8600-9250$ cal. yr BP). The time of the transgression is determined to $c .3750 \mathrm{cal}$. yr BP based on a macrofossil sample containing Hippuris vulgaris, Empetrum sp., Potamogeton sp., Bryopsida indet., leaf fragment, twig fragment and Vaccinium uliginosum (3610-3880 cal. yr BP) taken from the transgression event at $5-11 \mathrm{~cm}$ level (Table 2). This date indicates a slow late Holocene relative sea-level rise as the basin is isolated during low tide today.

\section{Lake $Q 4\left(N 60^{\circ} 40.668^{\prime}, W 46^{\circ} 05.267^{\prime}\right),+12.3 m$}

This marsh-like lake is located on the island of Akia (Fig. 1). The threshold, located towards the northeast, consists of small boulders on bedrock at an altitude of $12.3 \mathrm{~m}$ a.h.a.t. and, because of its direction and location between higher elevated bedrock somewhat inland, it must have been sheltered before and during the isolation. With an irregular shape, the basin measures c. $50 \times 100 \mathrm{~m}$. There is no obvious inlet to the lake, so inflow of material is limited to surface runoff. The water depth at the coring site is $0.7 \mathrm{~m}$ and the maximum depth is $0.9 \mathrm{~m}$. Sedimentary changes from sandy clayey gyttja silt into laminated sandy silty detritus gyttja are visible at the sharp isolation contact at $288.2 \mathrm{~cm}$ (Fig. 2C). Brown algae and Tricladida disappear at the isolation and freshwater organisms start to dominate with Cladocera, Chironomidae, Chara sp. and Hippuris vulgaris appearing and increasing in abundance (Fig. 3C). The magnetic susceptibility 
results show a sharp decrease at $288.2 \mathrm{~cm}$. XRF results show that all measured elements decrease except copper, which increases at the same level. The age of the isolation is established at c. 9125 cal. yr BP based on a macrofossil sample (8750-9500 cal. yr BP; Table 2) of Hippuris vulgaris, Batrachium confervoides, Nitella sp. and Bryopsida indet. taken above the isolation contact.

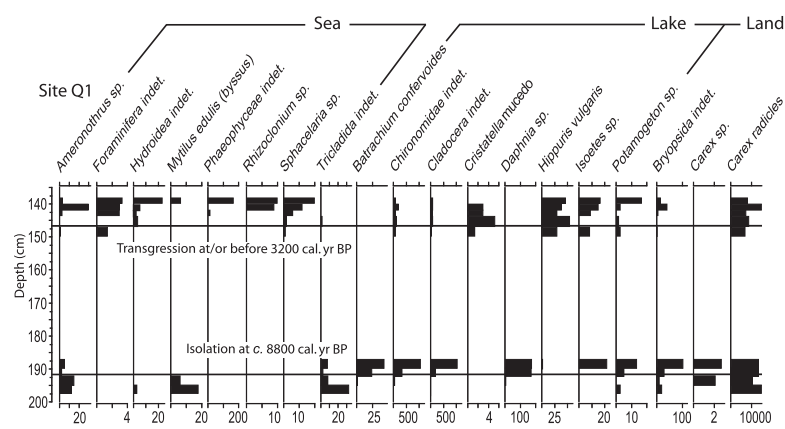

A

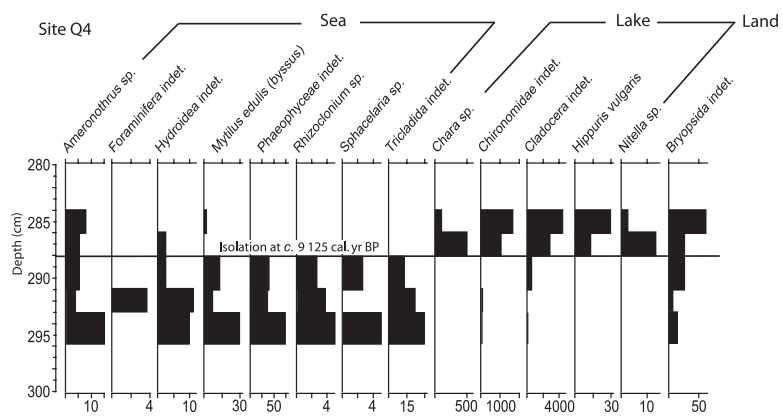

C

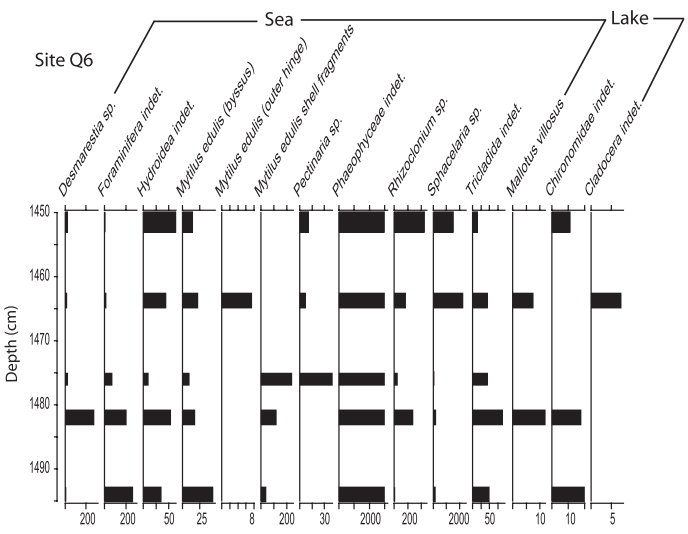

$\mathrm{E}$

Fig. 3. Simplified macrofossil diagram showing results from the macrofossil analyses of (A) site Q1, (B) site Q3, (C) site Q4, (D) site Q5, (E) site Q6, (F) site Q9, (G) site K1, (H) site K3, (I) site I1, (J) site Nu1. Note the different scales for the different taxa.

\section{Lake Q5 ( $\left.N 60^{\circ} 40.648^{\prime}, W 46^{\circ} 04.707^{\prime}\right),+22.3 \mathrm{~m}$}

This lake, too, is also located on the island of Akia (Fig. 1). The threshold consists of boulders on bedrock at an altitude of $22.3 \mathrm{~m}$ a.h.a.t. and because of its location on a watershed at the coast it must have been exposed to stormy weather before and at the time of isolation. With an irregular shape, the basin

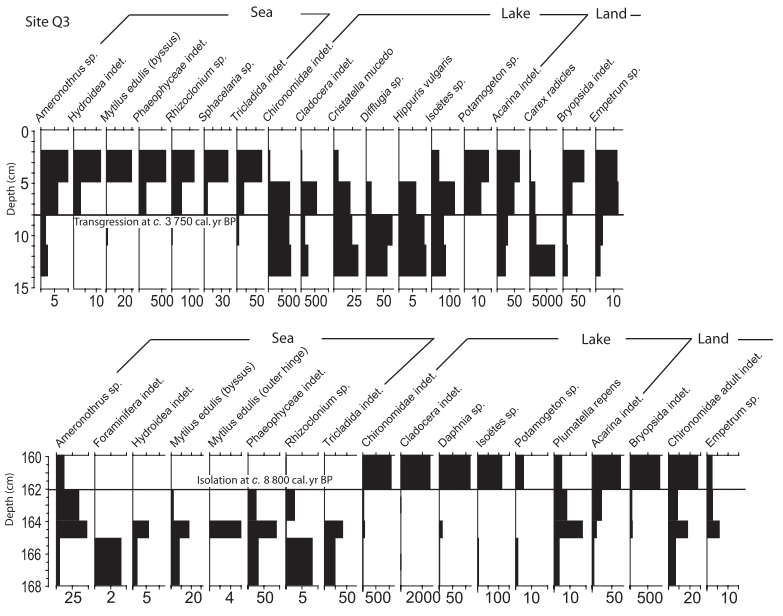

B

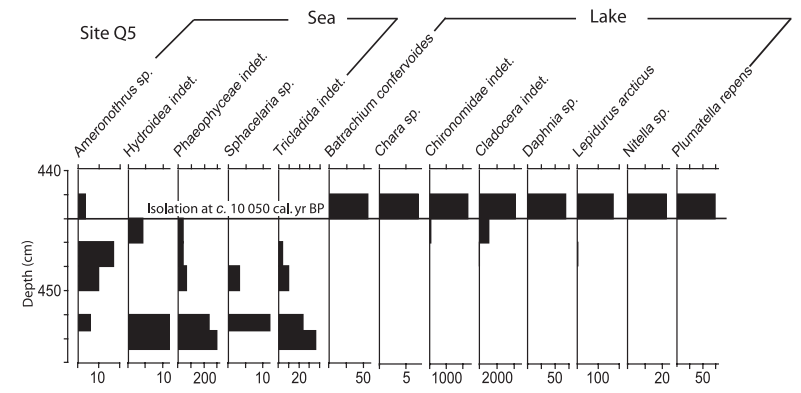

D

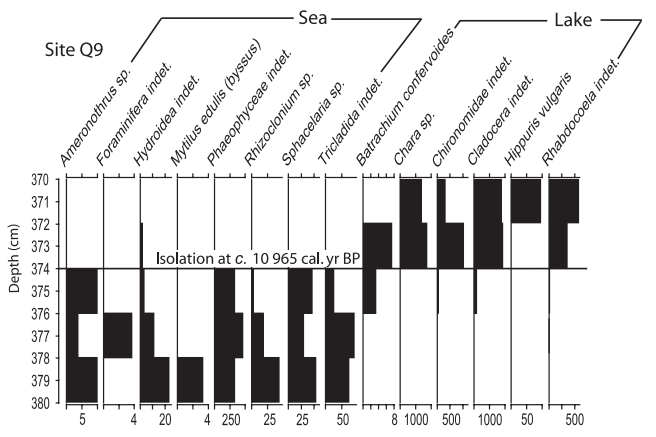

$\mathrm{F}$ 

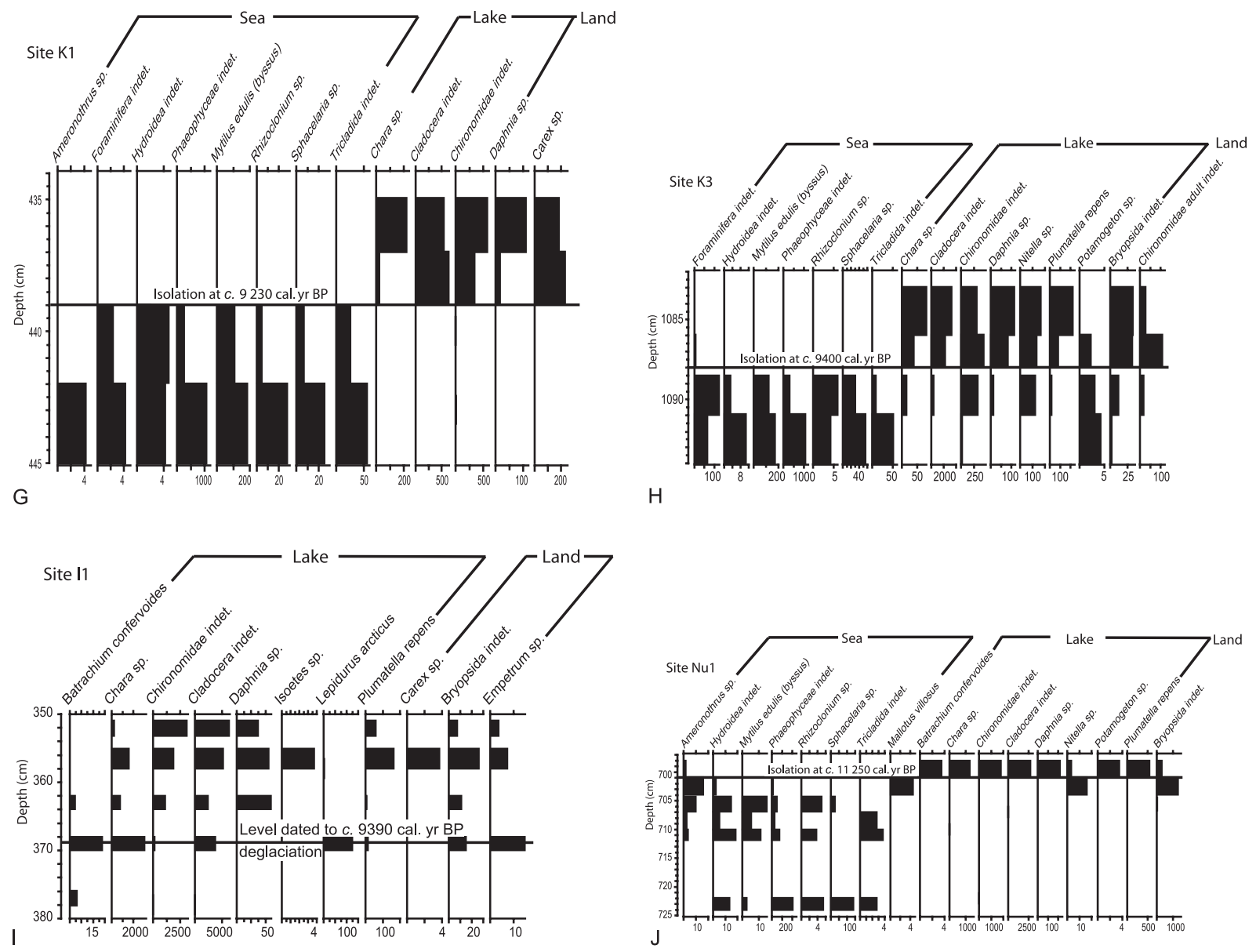

Fig. 3 (Continued)

measures $c .250 \times 250 \mathrm{~m}$. There are no inlets to the lake, and, because of its location on the watershed, inflow from surface runoff must be limited. Water depth at the coring site is $2.1-2.2 \mathrm{~m}$ and maximum depth is $3.7 \mathrm{~m}$. The isolation contact at $444 \mathrm{~cm}$ depth is seen in the sediments as a change from laminated sandy silty gyttja and silty gyttja sand into sandy silty gyttja continuing into vaguely laminated silty gyttja (Fig. 2D). Brown algae and Tricladida disappear in the sediments at the isolation and freshwater fossils start to dominate with Cladocera, Chironomidae, Lepidurus arcticus and Plumatella repens appearing and increasing in abundance (Fig. 3D). The magnetic susceptibility results show a sharp decrease at $444 \mathrm{~cm}$ as do the XRF-scanned elements potassium, calcium, titanium, manganese and iron. The cobalt and strontium counts show large fluctuations and no distinct pattern is seen in these elements. The copper counts show an increase just before the isolation. The age of the isolation is established at c. 10050 cal. yr BP (9860-10 230 cal. yr BP, Table 2) based on a macrofossil sample of Chara sp., Juniperus sp.,
Empetrum sp., Batrachium confervoides, Bryopsida indet., Nitella sp. and Daphnia sp. collected above the isolation contact.

\section{Marine lagoon $Q 6$ ( N $\left.60^{\circ} 40.822^{\prime}, W 46^{\circ} 04.967^{\prime}\right)$, $-8.7 m$}

This basin is a marine embayment located on Akia (Fig. 1) and its threshold is oriented towards the northeast. The threshold consists of bedrock and boulders with the lowest point at $-8.7 \mathrm{~m}$ b.h.a.t. The lagoon is sheltered from stormy weather as the fetch from the northeast is short and limited. A river drains into the basin and the topography of the landscape suggests a high inflow of sediments from surface runoff. The basin is circular in form and measures $c$. $250 \times 250 \mathrm{~m}$ with a maximum depth of $c .22-24 \mathrm{~m}$. The water depth at the coring site varied between 12.75 and $13.7 \mathrm{~m}$ due to the change in tide during the coring. No isolation contact is found in the sediments retrieved from this basin, so either it has not been isolated or sediments are missing as a result of erosion. The bottom of the retrieved cores contains $15 \mathrm{~cm}$ of sandy 


\begin{tabular}{|c|c|c|c|c|c|c|}
\hline Site & Lab. no. & Depth (cm) & Age, ${ }^{14} \mathrm{C}$ yr BP & Calibrated age yr BP $2 \mathrm{~s}(95.4 \%)$ & Comments & Material \\
\hline I1 & Poz-7191 & $355-356$ & $8030 \pm 40$ & $8750-9030(95.4 \%)$ & Deglaciation & Gyttja \\
\hline I1 & LuS-5862 & $368-370$ & $8370 \pm 70$ & $\begin{array}{l}9200-9530(92.3 \%) \\
9140-9180(3.1 \%)\end{array}$ & Deglaciation & Empetrum, Batrachium, Scirpus, Chara \\
\hline $\mathrm{K} 1$ & LuS-5960 & $437.5-439$ & $8255 \pm 70$ & $9030-9430(95.4 \%)$ & Isolation & Carex \\
\hline $\mathrm{K} 1$ & LuA-5824 & $437.5-439$ & $9420 \pm 60$ & $\begin{array}{l}10950-11100(4.2 \%) \\
10400-10800(91.2 \%)\end{array}$ & Isolation & Gyttja \\
\hline $\mathrm{K} 3$ & LuA-5826 & $1087-1087.5$ & $7760 \pm 110$ & $8350-9000(95.4 \%)$ & Isolation & Gyttja \\
\hline $\mathrm{K} 3$ & LuS-5910 & $1087-1088$ & $8404 \pm 80$ & $\begin{array}{l}9240-9540(93.2 \%) \\
9140-9180(2.2 \%)\end{array}$ & Isolation & Gyttja \\
\hline $\mathrm{K} 3$ & LuS-5911 & $1089-1090$ & $8505 \pm 70$ & $\begin{array}{l}9390-9610(92.7 \%) \\
9310-9360(2.7 \%)\end{array}$ & Isolation & Gyttja silt \\
\hline $\mathrm{K} 3$ & LuS-5919 & $1083-1091$ & $8155 \pm 50$ & $9000-9270(95.4 \%)$ & Isolation & $\begin{array}{l}\text { Chara, Bryopsida, leaf, Potamogeton, Nitella } \\
\text { Chironomidae, Juniperus, Empetrum, } \\
\text { Daphnia }\end{array}$ \\
\hline $\mathrm{Nu} 1$ & LuS-5920 & 696-698 & $9700 \pm 60$ & $\begin{array}{l}11060-11240(65.6 \%) \\
10790-10970(27.8 \%) \\
11000-11030(2 \%)\end{array}$ & Isolation & Chara, Bryopsida \\
\hline $\mathrm{Nu} 1$ & LuS-5878 & $698-701$ & $9845 \pm 60$ & $11160-11410(95.4 \%)$ & Isolation & $\begin{array}{l}\text { Chara, Batrachium, Bryopsida, Nitella } \\
\text { Potamogeton }\end{array}$ \\
\hline Q1 & LuS-5921 & $127.5-138$ & $230 \pm 70$ & $\begin{array}{l}60-470(84.4 \%) \\
-11-50(11 \%)\end{array}$ & Above transgression & $\begin{array}{l}\text { Empetrum, Hippuris, Potamogeton } \\
\text { Bryopsida, Leaf, Batrachium }\end{array}$ \\
\hline Q1 & LuS-5912 & $137-138$ & $1365 \pm 50$ & $1170-1360(95.4 \%)$ & Above transgression & Gyttja \\
\hline $\mathrm{Q} 1$ & LuS-5922 & $138-142$ & $965 \pm 50$ & $760-970(95.4 \%)$ & Just above transgression & Empetrum, Hippuris, Potamogeton, Leaf \\
\hline Q1 & LuS-5913 & $142-143$ & $2890 \pm 50$ & $\begin{array}{l}3180-3210(3.2 \%) \\
2870-3170(92.2 \%)\end{array}$ & Transgression & Gyttja \\
\hline Q1 & LuS-5927 & $187-190$ & $7835 \pm 60$ & $8450-9000(95.4 \%)$ & Just above isolation & $\begin{array}{l}\text { Empetrum, Hippuris, Carex, Potamogeton } \\
\text { Batrachium }\end{array}$ \\
\hline Q1 & LuS-5914 & $189.5-190$ & $7625 \pm 60$ & $8340-8550(95.4 \%)$ & Just above isolation & Gyttja \\
\hline Q1 & LuS-5926 & 190-197 & $7955 \pm 70$ & $8600-9000(95.4 \%)$ & Isolation & $\begin{array}{l}\text { Empetrum, Potamogeton, Bryopsida, Carex } \\
\text { Leaf, Batrachium }\end{array}$ \\
\hline Q3 & LuS-5923 & $5-11$ & $3470 \pm 50$ & $3610-3880(95.4 \%)$ & Transgression & $\begin{array}{l}\text { Hippuris, Empetrum, Potamogeton, Bryopsida } \\
\text { Leaf, Twig, Vaccinium }\end{array}$ \\
\hline Q3 & LuS-5915 & $10-11$ & $4370 \pm 60$ & $\begin{array}{l}5160-5280(9.9 \%) \\
5100-5130(1.1 \%) \\
4830-5070(84.4 \%)\end{array}$ & Below transgression & Gyttja \\
\hline Q3 & LuS-5916 & $15.0-15.8$ & $4590 \pm 60$ & $5040-5470(95.4 \%)$ & Below transgression & Gyttja \\
\hline Q3 & LuS-5918 & $161.0-161.8$ & $8060 \pm 70$ & $8600-9250(95.4 \%)$ & Isolation & Gyttja \\
\hline Q3 & LuS-5924 & $162-165$ & $7545 \pm 50$ & $\begin{array}{l}8280-8430(85.0 \%) \\
8200-8270(10.4 \%)\end{array}$ & Just below isolation & Phaecophyceae \\
\hline Q3 & LuS-5925 & $160-165$ & $7945 \pm 70$ & $8600-9000(95.4 \%)$ & Isolation & $\begin{array}{l}\text { Potamogeton, Bryopsida, Empetrum, Juniperus } \\
\text { Leaf, Salix, Hippuris, Carex, Isoëtes } \\
\text { Chironomidae } \\
\text { Daphnia, Plumatella }\end{array}$ \\
\hline Q3 & LuS-5917 & $315.5-316.5$ & $9830 \pm 100$ & $\begin{array}{l}11050-11750(90.4 \%) \\
10800-11000(5 \%)\end{array}$ & Deglaciation & Gyttja \\
\hline Q4 & LuS-5873 & $284-288$ & $8215 \pm 110$ & $8750-9500(95.4 \%)$ & Isolation & Hippuris, Batrachium, Nitella, Bryopsida \\
\hline $\begin{array}{l}\text { Q5 } \\
\text { Q5 }\end{array}$ & $\begin{array}{l}\text { LuS-5874 } \\
\text { LuS-5875 }\end{array}$ & $\begin{array}{l}400-400.5 \\
440-444\end{array}$ & $\begin{array}{l}7010 \pm 50 \\
8930 \pm 60\end{array}$ & $\begin{array}{r}7720-7950(95.4 \%) \\
9860-10230(93.4 \%) \\
9790-9850(2 \%)\end{array}$ & Isolation & $\begin{array}{l}\text { Gyttja } \\
\text { Chara, Juniperus, Empetrum, Batrachium }\end{array}$ \\
\hline Q6 & LuS-6075 & $14630-14650$ & $1255+50$ & $\begin{array}{l}9790-9850(2 \%) \\
1060-1290(95.4 \%)\end{array}$ & Lowest water level (?) & $\begin{array}{l}\text { Bryopsida, Nitella, Daphnia } \\
\text { Wood, leaf }\end{array}$ \\
\hline $\mathrm{Q} 9$ & LuS-5877 & $373.0-373.8$ & $9640 \pm 70$ & $10760-11200(95.4 \%)$ & Isolation & Gyttja \\
\hline Q9 & LuS-5876 & $372-374$ & $9615 \pm 60$ & $10750-11180(95.4 \%)$ & Isolation & Chara, Empetrum, Batrachium, Potamogeton \\
\hline
\end{tabular}


silty clay, possibly glacial clay, and on top of this $c$. $25 \mathrm{~cm}$ of clayey and sandy silt occurs with visible shell fragments (Fig. 2E). The rest of the sediment column is all gyttja dominated, except $10 \mathrm{~cm}$ at level 1459-1469.5 which contains silty gyttja sand. Macrofossil analyses have been carried out at lithological transitions and the results confirm the interpretations, with marine organisms, especially brown algae, dominating throughout the sediment column (Fig. 3E). Some freshwater organisms are present, but in small numbers and with few taxa represented. This can be expected as a river drains into the embayment. The magnetic susceptibility values are high in the lowest $40 \mathrm{~cm}$, coinciding with the minerogenic sediments in the bottom, and thereafter generally decrease in value (Fig. 2E). The XRF results do not show the obvious 'isolation pattern' seen in the other basins (Fig. 2E). One sample, consisting of wood and a piece of leaf, from level $1463-1465 \mathrm{~cm}$ gave an age of c. 1175 cal. yr BP (1060-1290 cal. yr BP; Table 2). At this level the sedimentation changes from more organic to more minerogenic composition, and this may imply a shift into a more energetic environment, i.e. a lower water level. As this basin does not show any isolation or transgression event, we interpret it as a lower limiting value: either the sea level has not been lower than this threshold, or sea level has been under or around the threshold altitude and the environment has been energetic and erosion has prevailed.

\section{Lake $Q^{9}\left(\mathrm{~N} 60^{\circ} 48.013^{\prime}, W 46^{\circ} 10.607^{\prime}\right),+31.0 \mathrm{~m}$}

The lake is located at the mouth of the Kangerluarsuk fjord (Fig. 1). The threshold, which constitutes the outlet of the lake, is oriented towards the west and consists of boulders on bedrock at an altitude of $31.0 \mathrm{~m}$ a.h.a.t. The lake is situated in a sheltered location and is of elongated shape of $c .100 \times 350 \mathrm{~m}$. There are no inlets to the lake and in-wash of sediments must therefore come from surface runoff alone. The water depth at the coring site corresponds to the maximum depth of $2.1 \mathrm{~m}$. The isolation contact at $374 \mathrm{~cm}$ is seen in the sediments as a change from clayey silty sand containing gravel particles into clayey silty gyttja sand continuing into detritus gyttja above the isolation contact (Fig. 2F). Brown algae, Tricladida and the oribatid mite Ameronothrus lineatus disappear in the sediments at the isolation and non-marine fossils start to dominate with Cladocera, Chironomidae, Rhabdocoela indet. and Chara sp. appearing and increasing in abundance (Fig. 3F). The magnetic susceptibility shows distinct peaks and fluctuations, 10 and $20 \mathrm{~cm}$ below the isolation, at which point the susceptibility decreases (Fig. 2F). The elements investigated by XRF-scanning all show a sharp decrease just below the isolation contact at $376 \mathrm{~cm}$. The exception is copper, which shows a marked increase at about that level (Fig. 2F). The age of the isolation is established at c. 10965 cal. yr BP based on one bulk sediment sample (10 760-11 200 cal. yr BP; Table 2) and one macrofossil sample of Chara sp., Empetrum sp., Batrachium confervoides and Potamogeton sp. (10 750-11 180 cal. yr BP; Table 2), both taken just above the isolation contact.

\section{Lake $\mathrm{Kl}\left(\mathrm{N} 60^{\circ} 52.014^{\prime}, W 45^{\circ} 56.866^{\prime}\right),+3.9 \mathrm{~m}$}

The lake is located on the northwest side of the Kangerluarsuk fjord (Fig. 1). It is well sheltered and with a highly irregular shape it measures c. $200 \times$ $200 \mathrm{~m}$. Its threshold, which corresponds to the present outlet of the lake, is oriented towards the southeast and consists of bedrock at an altitude of $3.9 \mathrm{~m}$ a.h.a.t. A series of lakes higher up in the terrain drains into the basin. The water depth at the coring site is $1.5 \mathrm{~m}$ and the maximum depth is $1.8 \mathrm{~m}$. The isolation contact at $439 \mathrm{~cm}$ is seen as a change from sandy gyttja silt into laminated sandy silty algal gyttja (Fig. 2G). Marine brown algae, Mytilus edulis, Tricladida and Foraminifera disappear in the sediments at the isolation and freshwater organisms start to dominate with Cladocera, Chironomidae and Chara sp. appearing and increasing in abundance (Fig. 3G). The magnetic susceptibility results show distinct peaks and fluctuations below the isolation. At the isolation, magnetic susceptibility falls suddenly and the curve flattens out with only minor fluctuations in the upper part of the sedimentary column (Fig. 2G). The elements investigated by XRF-scanning all show a sharp decrease at $439 \mathrm{~cm}$ except copper, which increases steadily below and at the isolation to level out and fluctuate around a higher number of counts in the rest of the sedimentary column (Fig. 2G). The age of the isolation is established at c. 9230 cal. yr BP based on a macrofossil sample of Carex sp. (9030-9430 cal. yr BP, Table 2) taken just at and above the isolation contact. A bulk sediment sample was taken from the same level and gave an age of c. 10700 cal. yr BP (10 400-10 800 cal. yr BP; Table 2). This is considered to be too old because of the mixing with older organic material present in the sediment matrix.

\section{Lake $K 3\left(N 60^{\circ} 49.050^{\prime}, W 46^{\circ} 00.446^{\prime}\right),+7.2 m$}

This lake is located adjacent to the Kangerluarsuk fjord (Fig. 1). The threshold, which corresponds also to the present outlet of the lake, is oriented towards the east and consists of boulders on bedrock at an altitude of $7.2 \mathrm{~m}$ a.h.a.t. There are no inlets and in-wash of sediments must come from surface runoff. The lake is in a sheltered location with an elongated shape of $c$. $500 \times 200 \mathrm{~m}$. The maximum water depth is $12.5 \mathrm{~m}$ and the depth at the coring site varied between 8.5 and $9.25 \mathrm{~m}$ as a consequence of shifting positions of the coring platform. The isolation contact at $1088 \mathrm{~cm}$ depth is seen in the sediments as a change from gravely 
sandy gyttja silt to laminated detritus gyttja containing silt and sand (Fig. 2H). Marine brown algae, Tricladida, Mytilus edulis and Foraminifera disappear in the sediments at the isolation and freshwater macrofossils start to dominate with cladocerans like Daphnia sp., Chironomidae, Plumatella repens and Nitella sp. appearing in increasing abundance (Fig. $3 \mathrm{H}$ ). The magnetic susceptibility curve shows distinct peaks in the bottom of the sedimentary column and one small peak before the isolation contact at $1093 \mathrm{~cm}$, but it then flattens out (Fig. 2H). The elements investigated by XRF-scanning all show a sharp decrease at $1088 \mathrm{~cm}$, except copper which increases steadily below and at the isolation (Fig. 2H). The isolation is dated to $c .9400 \mathrm{cal}$. yr BP based on two bulk sediment samples, one from above the isolation at $1087-1088 \mathrm{~cm} \mathrm{(9240-9540} \mathrm{cal.}$ yr BP; Table 2) and one from below the isolation at 1089-1090 cm (9390-9610 cal. yr BP; Table 2). Wellpreserved macrofossils were few around the isolation and the sample size was extended by including material from $5 \mathrm{~cm}$ above the isolation. This resulted in a macrofossil sample containing fossils younger than the actual isolation. Thus the sample from 1083$1091 \mathrm{~cm}$, containing Chara sp., Bryopsida indet., Leaf indet., Potamogeton sp., Nitella sp., Chironomidae adult et larvae, Juniperus sp. Empetrum sp. and Daphnia sp., gave an age of c. 9140 cal. yr BP (90009270 cal. yr BP; Table 2), which is considered to be too young.

\section{Lake I1 ( $\left.N 60^{\circ} 58.657^{\prime}, W 45^{\circ} 42.565^{\prime}\right),+39.7 m$}

The lake is located in the Tunulliarfik fjord area by the Ipiutaq farm (Fig. 1). The threshold corresponds to the lake outlet, which is oriented towards the southeast and consists of bedrock in a fluvial furrow at an altitude of $39.7 \mathrm{~m}$ a.h.a.t. There are no inlets to the lake and sediment inflow comes from surface runoff. The lake is in a sheltered valley location between two higher areas. It has a circular shape and measures $c .50 \times$ $75 \mathrm{~m}$. The water depth at the coring site is $0.9 \mathrm{~m}$ and the maximum depth is $1 \mathrm{~m}$. No marine sediments, and thus no isolation contact, are found in the sequence, so either it has not been isolated or sediments are missing as a result of erosion. However, the bottom sediments consist of $23 \mathrm{~cm}$ of gravely silty sand with pebbles and are interpreted as deglaciation sediments. A radiocarbon sample of Empetrum sp., Batrachium confervoides, Scirpus caespitosus and Chara sp. gave an age of c. 9365 cal. yr BP (9200-9530 cal. yr BP; Table 2) for these coarse bottom sediments. This can be regarded as a minimum age of deglaciation. The rest of the $176 \mathrm{~cm}$ of sediments consists of different gyttjas (Fig. 2I). Results from the macrofossil analyses (Fig. 3I) show a typical immigrational development of flora and fauna after the deglaciation with, for example, Lepidurus arcticus during a short initial stage, as is common in many lakes in southwest Greenland
(Bennike et al. 2004). Perched boulders in the immediate vicinity of the lake imply that the marine limit is lower than the lake threshold.

The magnetic susceptibility results show high values at the bottom, where the sediments are coarse and dominated by minerogenic material (Fig. 2I) and the values decrease upwards in the core as the organic content of the sediments increases. The elements investigated by XRF-scanning all show a decrease from the bottom until $350 \mathrm{~cm}$ level except copper, which shows the inverse trend (Fig. 2I). Above $350 \mathrm{~cm}$, all the elementary counts level out and continue to fluctuate around limited values. Neither the magnetic susceptibility nor XRF measurements indicate an isolation event, and these data strengthen the interpretation of the sediments being a deglaciation sequence. The altitude of this basin therefore constitutes an upper limit for relative sea level at this locality.

\section{Lake Nul ( $\left.N 61^{\circ} 07.319^{\prime}, W 45^{\circ} 37.711^{\prime}\right),+10 \mathrm{~m}$}

This lake is located by the Sermilik fjord (Fig. 1) and is situated furthest inland of the 10 investigated sites. Because of its inland location, it is potentially important for determining the gradient of the isobases as well as for determining the age of the ice retreat from the inner fjords. The threshold constitutes the outlet of the lake, is oriented towards the south and consists of sediments in a fluvial channel at an altitude of $9.6 \mathrm{~m}$ a.h.a.t. With regard to the local morphology, the outlet channel has not been significantly eroded or deepened. Therefore we place the threshold at $10 \mathrm{~m}$. Except for surface runoff, a stream transports water and material into the lake. Situated in a valley, the location is sheltered between three higher areas and the nearest marine water is a sheltered embayment. The lake has an elongated shape and measures $c .400 \times 125 \mathrm{~m}$. The water depth at the coring site is between 1.55 and $1.65 \mathrm{~m}$, varying as a consequence of shifting positions of the coring platform. Maximum depth in the lake is $1.7 \mathrm{~m}$. In the bottom $15 \mathrm{~cm}$ of the sequence, gravely sandy silty clay changes into silty sand and above this it changes into laminated silty sand and detritus gyttja (Fig. 2J). Below the isolation contact at $701 \mathrm{~cm}$, a sedimentary change to laminated sandy silty detritus gyttja appears but the lamination is less well defined higher in the succession. Marine brown algae and Hydroidea disappear at the isolation contact and freshwater organisms appear with Cladoceras like Daphnia sp., Chironomidae, Plumatella repens and Chara sp. increasing in abundance just above the isolation contact (Fig. 3J). Magnetic susceptibility attains high values in the lowest part of the sediment column, but decreases upwards with a small peak just above the isolation, and then the magnetic susceptibility curve flattens out (Fig. 2J). The elements investigated by XRF-scanning all show a sharp decrease at $701 \mathrm{~cm}$, except copper, which increases 
distinctly, and strontium, which shows a gradual decrease. The age of the isolation is established at c. 11250 cal. yr BP based on two macrofossil samples; one from $3-5 \mathrm{~cm}$ above the isolation (11 060-11 240 cal. yr BP; Table 2) containing Chara sp., Bryopsida indet.; and one collected at and just above the isolation at $698-701 \mathrm{~cm}$ (11 160-11 $410 \mathrm{cal}$. yr BP; Table 2) containing Chara sp., Batrachium confervoides, Bryopsida indet., Nitella sp. and Potamogeton sp.

This site differs from the others in some important ways: it has a 'soft' threshold, it is situated furthest inland and its isolation age is the oldest obtained in the study area. However, because of its sheltered position, the absence of any erosion channels and the low water transport through the outlet, we consider that the sediment threshold has remained unaltered. The isolation age also represents a minimum deglaciation age and the relatively early age may indicate that the deep, straight and wide Sermilik (Bredefjord) acted as a calving bay/fjord with a floating glacier disintegrating rapidly during the Lateglacial and earliest Holocene.

\section{Discussion}

\section{Isolation - from glaciomarine conditions into a freshwater environment}

As in the previously investigated Nanortalik area (Sparrenbom et al. 2006), early Holocene isolation sequences from the Qaqortoq area show abrupt lithological changes from coarser minerogenic sediments deposited in a (glacio)marine environment to laminated sediment, often with dark iron sulphide-rich laminations deposited in a brackish environment, and often abruptly shifting into a freshwater deposited brownish algae gyttja. Pre-isolation sediments are dominated by macrofossils of marine brown algae such as Rhizoclonium sp. and Sphacelaria sp. Also common in the marine sediments are the blue mussel Mytilus edulis, hydrozoans of the order Hydroidea, flatworms of the order Tricladida and Foraminifera. Bone remains from capelin (Mallotus villosus) have been found in one of the basins below the isolation contact. Non-marine fossils are often present in small numbers in sediments dominated by marine organisms, a consequence of in-wash from rivers, streams and surface runoff. No obvious differences can be seen in the amount of non-marine organisms deposited in basins without an inflow from a river or a stream, as opposed to a basin with an obvious inflow. The availability and establishment of freshwater taxa in the neighbouring area may instead be the controlling factors. In connection with isolations and transgressions, the oribatid mite Ameronothrus lineatus appears in the sediments, possibly favoured by the brackish transitional environment. This oribatid lives at or near the sea shore (Hammer 1944) and has been reported from isolation sequences by Bennike (1992, 1995), Bennike et al. (2002) and Sparrenbom et al. (2006). The presence of marine organisms often ends abruptly at the isolation contact, to be followed directly by freshwater taxa. Most of the freshwater organisms enter the isolated lake by surface runoff and streams, but some species may also have been transported by birds. The most commonly found remains of freshwater organisms are ephippia of cladocerans, larval head capsules of chironomids, oospores of the greenalgae Nitella sp. and Chara sp., megaspores of Isoëtes sp., statoblasts of Plumatella repens, achenes of the water-crowfoot Batrachium confervoides, some Lepidurus arcticus eggs and Hippuris vulgaris fruits.

\section{Basin ingression - from freshwater into a brackish/marine environment}

The transition from freshwater sediments into marine sediments is not as clearly visible as the isolation contacts. This is, as in the Nanortalik area (Sparrenbom et al. 2006), a consequence of the rate of sea-level change being high during the time of isolation and low during the transgression. The changes in the sediments are gradual and it is therefore difficult to define a 'transgression contact'. Physically, the change is often seen as an increased amount of mineral particles with higher magnetic susceptibility values. The results from the XRF-scanning of the transgression sequence from site Q3 show a reverse trend to the isolation contacts scanned, that is an increase in all elements measured, except copper, which decreases. The macrofossil analyses show gradual environmental changes with several marine species appearing in small numbers concurrently with a gradual decline of freshwater species and numbers of individuals. It is common to find both marine and freshwater species in large numbers in the first centimetres of the sediment column above the marine ingression. Freshwater species tolerating slightly brackish conditions increase in numbers just after the marine ingression. The increase may result from less competition occurring as freshwater taxa intolerant of brackish conditions disappear. The first migrating marine taxa are often brown algae like Sphacelaria sp. and Rhizoclonium sp., the bivalve Mytilus edulis, hydrozoans of the order Hydroidea and flatworms of the order Tricladida.

Worth noticing from the sites with transgression sequences, Q1 and Q3, is the occurrence of Cristatella mucedo in the sediments below the marine ingression. The distinctive statoblasts of the freshwater bryozoan have previously only been found in sediments from southern Greenland from the time period 2600 to 3600 ${ }^{14} \mathrm{C}$ yr BP (Fredskild et al. 1975), corresponding to $c$. 2050-4650 cal. yr BP. In the sediments from site Q1, Cristatella mucedo is found in sediments as young 


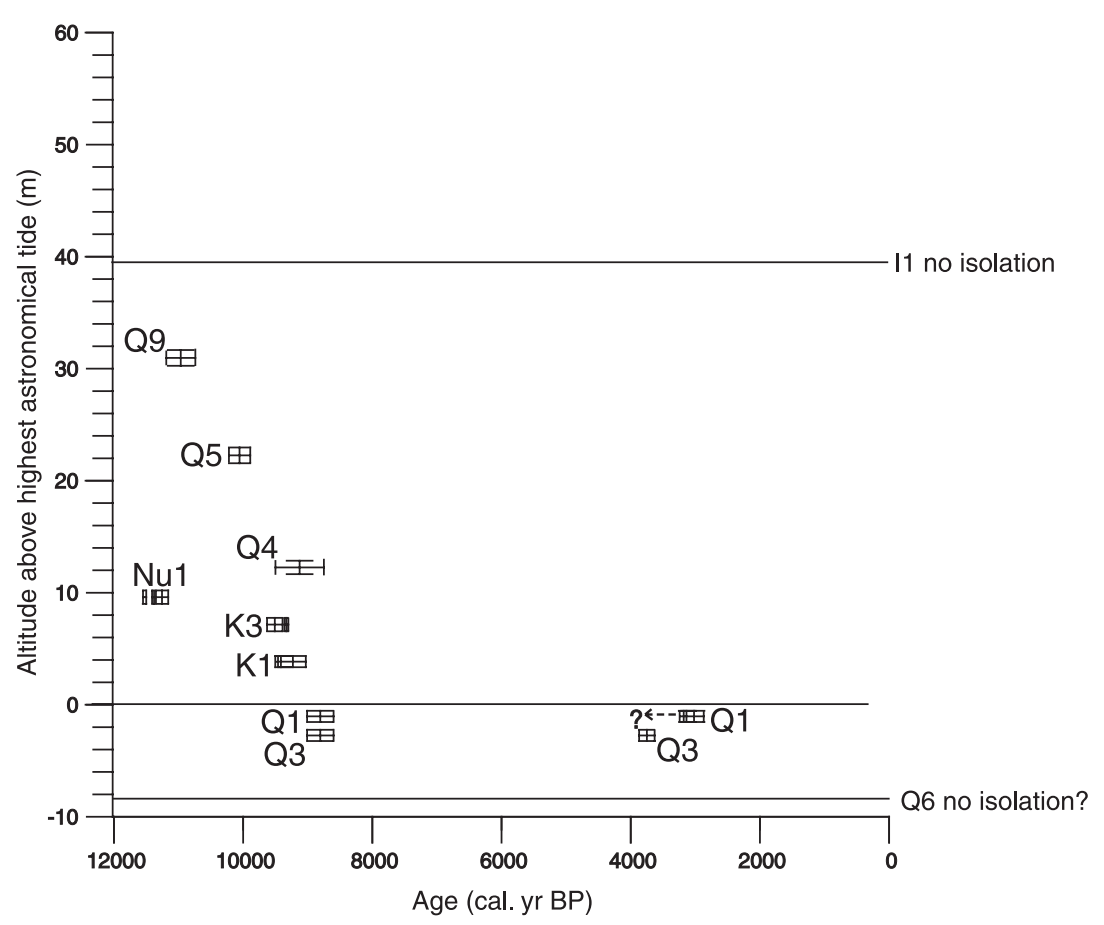

Fig. 4. Relative sea-level change in the Qaqortoq area during the Holocene as indicated by the presence or absence of isolation and transgression events or by deglaciation ages in a total of 10 different basins. Altitude errors are listed in Table 1 and age error bars of $2 \sigma$ are shown as given in Table 2. Some age spans are divided into two or three periods. No isolation or transgression is found in basins Q6 and I1; these two basins provide a minimum and maximum altitude, respectively. Their thresholds are marked in the diagram with horizontal lines giving the maximum and minimum altitudes. The transgression age for site Q1 is a minimum date taken from a sample some $5 \mathrm{~cm}$ above the first marine ingression. as c. 1000 cal. yr BP and in Q3 in sediments as old as 4950 cal. yr BP.

\section{Relative sea-level changes in the Qaqortoq area}

The isolation and transgression ages in Fig. 4 summarize the relative sea-level change at the 10 sites described in this article. Spatial variation of isostatic uplift between the coastal and more inland sites is potentially important, but from the available sea-level data alone the true gradients of sea-level isobases cannot be established and it is not possible to reduce the data for differential rebound. But while this record should not be interpreted as a shoreline displacement curve for any specific locality, it does provide an indicative local relative sea-level curve for the Qaqortoq area, since much of the evidence derives from the closely clustered group of isolation basins Q1 and Q3-Q6 which will have experienced only little differential isostatic rebound. Of these sites, no isolation or transgression has been identified in Q6 and this determines the lower limit to the postglacial sea level in this area. The highest observed level showing an isolation sequence is the Q9 site, c. $10 \mathrm{~km}$ inland from the main group. The upper limit is defined between this level and the level of site I1 further inland, where no isolation was identified. Perched boulders have been found on the island of Akia at around 52-54 $\mathrm{m}$ a.h.a.t. indicating the highest marine limit of the area. Perched boulders were observed in the inner Kangerluarsuk fjord at c. $50 \mathrm{~m}$ a.h.a.t and around the Ipiutaq farm at c. $40-$ $45 \mathrm{~m}$ a.h.a.t.
The Qaqortoq results indicate a local emergence rate of $c .2 \mathrm{~m} / 100$ years between $c .10000$ cal. yr BP (Q5) and c. 8800 cal. yr BP (Q3) and an absolute value for land uplift of $3-3.5 \mathrm{~m} / 100 \mathrm{yr}$ if sea-level rise is taken into account (Lambeck \& Chappell 2001). These high uplift rates in the Q1-Q6 area imply a rapid recession of the ice sheet during at least parts of the Lateglacial and the early Holocene.

We conclude that the regression minimum was reached between 8000 and 4000 cal. yr BP, with the most likely age at 8000 to 6000 cal. yr BP, and with an altitude between -3 and $-8.5 \mathrm{~m}$. This is also the age found for the regression minimum in the Nanortalik area (Sparrenbom et al. 2006). The onset of transgression by or before 4000 cal. yr BP could reflect a readvance of the Greenland Ice Sheet superimposed on the isostatic signal from the North American Ice Sheet. The suggestion by Weidick et al. (2004), in which the ice sheet margin reached its present-day position at around 9500 cal. yr BP and during 9000-3000 cal. yr BP the ice margin occurred further inland, is qualitatively consistent with our sea-level observations. Fleming \& Lambeck (2004) also suggested that the ice sheet retreated behind present-day margin by distances in the order of $40 \mathrm{~km}$ before re-advancing.

In contrast to the early rapid relative sea-level fall, the mid-to-late Holocene transgression has been slow and gradual, and while impossible to conclude precisely when sea level reached present-day level in the area, we show that it occurred some time after 2000 cal. yr BP. 
The isolation ages for $\mathrm{K} 1, \mathrm{~K} 3$ and $\mathrm{Q} 4$ are statistically equivalent (c. 9200-9000 cal. yr BP), and they suggest the gradient of the isobases at c. 9000 cal. yr BP of c. $4 \mathrm{~m} / 10 \mathrm{~km}$ in a northeasterly direction towards the present ice sheet. Similarly, Nu1 and Q9 are of comparable age (c. $11200-11000$ cal. yr BP) and indicate a tilt of almost $5 \mathrm{~m} / 10 \mathrm{~km}$ also in a northeasterly direction. These gradients are comparable in magnitude to those found in completely deglaciated regions, e.g. Scandinavia (SW Sweden by Björck \& Digerfeldt (1991); western-central Norway by Kjemperud (1986); eastern Sweden by Berglund (2004)), but there they are directed towards the periphery of the former ice sheet. The opposite direction found here is the result of the incomplete deglaciation, i.e. most of the ice that has disappeared since the LGM until the present-day has been removed from the shelf and coastal areas rather than from the interior. The northeasterly dipping shorelines show that the uplift rate was smaller further inland than in the coastal areas. The same type of behaviour, but on a larger scale, has been reported from Antarctica (Zwartz et al. 1999) and reflects the incomplete deglaciation of the region.

As concluded by Sparrenbom et al. (2006), poor agreement is found between results from glacialisostatic adjustment models reconstructing relative sea level with those observations available at present (Bennike et al. 2002; Tarasov \& Peltier 2002; Fleming $\&$ Lambeck 2004). The comparison between observations and predictions is clearly unsatisfactory in previous modelling attempts, and Bennike et al. (2002) and Fleming \& Lambeck (2004) conclude that their models underestimate the reduction in ice thickness and that the deglaciation chronology needs to be considered in more detail. Previous studies as well as the observations presented here and in Sparrenbom et al. (2006) imply rapid recession and thinning of the ice sheet before the earliest isolations. A new and more extensive modelling analysis can be made from these observations to better elucidate the changes in ice volume and the Lateglacial and Holocene history of the southern part of the Greenland Ice Sheet.

Our results can partly explain why evidences for the presence of some Palaeo-Eskimo cultures are extremely rare in southern Greenland, even though recent investigations by Raahauge et al. (2005) show that the Dorset culture actually reached the area. Ruins originally situated close to the shoreline are likely to have been washed away as the relative sea level has risen $c$. $0.5-1 \mathrm{~m}$ since the time of their presence at c. 2600 cal. yr BP. If the earlier Palaeo-Eskimo cultures reached southern Greenland, their settlements are likely to be found below present-day sea level because local sea level has risen around $3 \mathrm{~m}$ since $4000 \mathrm{yr}$ BP in the Qaqortoq area.

\section{Conclusions}

High quality observations of Holocene relative sealevel change in southern Greenland are scarce and have mostly been restricted to observations from the Nanortalik area (Bennike et al. 2002; Sparrenbom et al. 2006) with only a few scattered observations from other localities (Fredskild 1973; Funder 1979; Weidick et al. 2004). Our new data from the Qaqortoq area add significantly to this data set. The investigation demonstrates that the local sea level reached $31.0 \mathrm{~m}$ above present h.a.t. c. 10965 cal. yr BP and fell rapidly to just above $-8.7 \mathrm{~m}$ b.h.a.t. by $8000-6000$ cal. yr BP. Compared with the results from the Nanortalik area (Sparrenbom et al. 2006), most of the ice retreat occurs later in the Qaqortoq area as a consequence of the site's more inland position. The data also suggest that relative sea level reached slightly lower altitudes in the Nanortalik area than in the Qaqortoq area, consistent with the more inland position of the Qaqortoq area and possibly reflecting differences in ice thickness, i.e. differences in ice load changes, between the two areas. The mid-Holocene transgression seems to have reached present-day sea levels earlier in the Qaqortoq area than in the Nanortalik area, which as a consequence of the closer proximity to the ice mass centre in the Qaqortoq area may imply that the transgression was caused by a Holocene thickening of the Greenland Ice Sheet. Based on the studies from the Qaqortoq and Nanortalik areas, we can draw the following conclusions about sea-level changes in southern Greenland:

- In both the Nanortalik and the Qaqortoq area the relative sea-level fall in the Lateglacial and earliest Holocene was rapid at the time when the area became ice-free, whereas the relative sea-level rise in the mid to late Holocene was slow and gradual.

- The shorelines from around $11000 \mathrm{cal}$. yr BP slope almost $5 \mathrm{~m} / 10 \mathrm{~km}$ towards the Greenland Ice Sheet in the northeast, while younger shorelines, at c. 9000 cal. yr BP, slope $c .4 \mathrm{~m} / 10 \mathrm{~km}$. The northeasterly sloping shorelines show that the uplift rate was smaller in the inland than at the outer coast, indicating that the rebound is responding primarily to a removal of ice from the coastal and shelf zone.

- From the two sites Q5 and Q3, with an altitude difference of $25 \mathrm{~m}$, the relative uplift during the time period between $c .10000$ and 8800 cal. yr BP can be approximated to $c$. $2 \mathrm{~m} / 100 \mathrm{yr}$. This gives an absolute value for land uplift of $3-3.5 \mathrm{~m} / 100 \mathrm{yr}$ for this area. The relative sea level reached below $2.7 \mathrm{~m}$ at $8800 \mathrm{cal}$. yr BP and continued to fall for some time. This implies a fast recession of the ice sheet during parts of the Lateglacial and the early Holocene. 
- Between 8000 and 6000 cal. yr BP, sea level in the Qaqortoq area reached its lowest level probably around -6 to $-8 \mathrm{~m}$.

- During the mid to late Holocene, at around 3750 cal. yr BP, sea level again reached above $-2.7 \mathrm{~m}$ and continued to rise slowly. The mean submergence of the area during this time interval was $c .3 \mathrm{~mm} / \mathrm{yr}$.

Acknowledgements. - We thank the Royal Physiographic Society in Lund, Lars Hierta Memory Foundation, the Craaford Foundation, Lund University Faculty of Science, the Alice and Knut Wallenberg Foundation, and the Swedish Society of Anthropology and Geography for funding this study and the Swedish Polar Secretariat for logistic support. We thank Helena Alexanderson, Karl Ljung and Niklas Sparrenbom for help in the field, Georg Nyegaard for help with information, logistic and fruitful discussions. Marloes Kortekaas is gratefully acknowledged for introducing us to XRF-scanning. Kurt Lambeck thanks the Swedish Research Council for financial support as Tage Erlander Professor. We thank Niklas Sparrenbom for laboratory work, Kevin Fleming for fruitful discussions, Hans F. Jepsen at GEUS for photogrammetric measurements, Palle Bo Nielsen at Farvandsvæsenet for making tidal charts accessible and for discussions on tidal issues, Ole Andersen at the National Survey and Cadastre in Copenhagen for calculating the astronomical tides, Poul Møller Pedersen, Lena Barnekow and Gunnar Digerfeldt for support in identifying macrofossils and all others who in any way have contributed to this investigation.

\section{References}

Bak, O. 1969: Herjolfsnæs. Grønland 1969, 349-352.

Bennike, O. 1992: Palaeoecology and paleoclimatology of a late Holocene peat deposit from Brændevinsskær, central West Greenland. Arctic and Alpine Research 24, 249-252.

Bennike, O. 1995: Palaeoecology of two lake basins from Disko, West Greenland. Journal of Quaternary Science 10, 149-155.

Bennike, O. \& Weidick, A. 2001: Late Quaternary history around Nioghalvfjerdsfjorden and Jøkelbugten, North-East Greenland. Boreas 30, 205-227.

Bennike, O., Björck, S. \& Lambeck, K. 2002: Estimates of South Greenland late-glacial ice limits from a new relative sea-level curve. Earth and Planetary Science Letters 197, 171-186.

Bennike, O., Brodersen, K. P., Jeppesen, E. \& Walker, I. R. 2004: Aquatic invertebrates and high-latitude palaeolimnology. In Pienitz, R., Douglas, M. S. V. \& Smol, J. P. (eds.): Long-term Environmental Change in Arctic and Antarctic Lakes, 159-186. Kluwer Academic Publishers, Dordrecht.

Berglund, M. 2004: Holocene shore displacement and chronology in Angermanland, eastern Sweden, the Scandinavian glacio-isostatic uplift centre. Boreas 33, 48-60.

Björck, S., Bennike, O., Ingólfsson, Ó., Barnekow, L. \& Penney, D. N. 1994: Lake Boksehandsken's earliest postglacial sediments and their palaeoenvironmental implications, Jameson Land, East Greenland. Boreas 23, 459-472.

Björck, S. \& Digerfeldt, G. 1991: Allerød-Younger Dryas sea-level changes in the southwestern Sweden and their relation to the Baltic Ice Lake development. Boreas 20, 115-133.

Björck, S. \& Persson, T. 1981: Late Weichselian and Flandrian biostratigraphy and chronology from Hochstetter Forland, Northeast Greenland. Meddelelser om Grønland, Geoscience 5, 19 pp.

Daryin, A. V., Kalugin, I. A., Maksimova, N. V., Smolyaninova, L. G. \& Zolotarev, K. V. 2005: Use of a scanning XRF analysis on SR beams from VEPP-3 storage ring for research of core bottom sediments from Teletskoe Lake with the purpose of high resolution quantitative reconstruction of last millennium paleoclimate. $\mathrm{Nu}$ clear Instruments and Methods in Physics Research A 543, 255-258.

Farvandsvæsenet, 2000: Tidevandstabeller 2001 for grønlandske farvande. Farvandsvasenet, København.

Farvandsvæsenet, 2001: Tidevandstabeller 2002 for grønlandske farvande. Farvandsvasenet, København.

Fleming, K. \& Lambeck, K. 2004: Constrains on the Greenland Ice Sheet since the Last Glacial Maximum from sea-level observations and glacial-rebound models. Quaternary Science Reviews 23, $1053-1077$.

Fredskild, B. 1973: Studies in the vegetational history of Greenland, palaeobotanical investigations of some Holocene lake and bog deposits. Meddelelser om Grønland 198, 245 pp.

Fredskild, B., Jacobsen, N. \& Røen, U. 1975: Remains of mosses and freshwater animals in some Holocene lake and bog sediments from Greenland. Meddelelser om Grønland 198, 44 pp.

Funder, S. 1978: Holocene stratigraphy and vegetation history in the Scoresby Sund area, East Greenland. Gronlands Geologiske Undersogelse, Bulletin 129, 66 pp.

Funder, S. 1979: The Quaternary geology of the Narssaq area, South Greenland. Gronlands Geologiske Undersogelse 86, 24 pp.

Gabel-Jørgensen, C. C. A. \& Egedal, J. 1940: Tidal observations made at Nanortalik and Julianehåb in 1932-1934. Meddelelser om Grønland 107, 47 pp.

Hammer, M. 1944: Studies on the Orbatids and Collemboles of Greenland. Meddelelser om Grønland 141, $210 \mathrm{pp}$.

Jansen, J. H. F., Van der Gaast, S. J., Koster, B. \& Vaars, A. J. 1998: CORTEX, a shipboard XRF-scanner for element analyses in split sediment cores. Marine Geology 151, 143-153.

Kelly, M., Funder, S., Houmark-Nielsen, M., Knudesen, K. L., Kronborg, C., Landvik, J. \& Sorby, L. 1999: Quaternary glacial and marine environmental history of northwest Greenland: a review and reappraisal. Quaternary Science Reviews 18, 373-392.

Kjemperud, A. 1986: Late Weichselian and Holocene shoreline displacement in the Trondheimsfjord area, central Norway. Boreas $15,61-82$.

Kuijpers, A., Abrahamsen, N., Hoffman, G., Hühnerbach, V., Konradi, P., Kuzendorf, H., Mikkelsen, N., Thiede, J. \& Weinrebe, W. (1999) Shipboard scientific party of RV Poseidon and surveyors of the Royal Danish Administration for Navigation and Hydrography. Geology of Greenland Survey, Bulletin 183, 61-67.

Lambeck, K. \& Chappell, J. 2001: Sea level change through the last glacial cycle. Science 292, 679-686.

Lamy, F., Hebbeln, D., Röhl, U. \& Wefer, G. 2001. Holocene rainfall variability in southern Chile: a marine record of latitudinal shifts of the Southern Westerlies. Earth and Planetary Science Letters 185, $369-382$.

Long, A. J. \& Roberts, D. H. 2002: A revised chonology for the 'Fjord Stade' moraine in Disko Bugt, west Greenland. Journal of Quaternary Science 17, 561-579.

Long, A., Roberts, D. H. \& Wright, M. R. 1999: Isolation basin stratigraphy and Holocene relative sea-level change on Arveprinsen Ejland, Disko Bugt, West Greenland. Journal of Quaternary Science 14, 323-345.

Long, A. J., Roberts, D. H. \& Rasch, M. 2003: New observations on relative sea level and deglacial history of Greenland from Innaarsuit, Disko Bugt. Quaternary Research 60, 162-171.

Mathiassen, T. 1936: The eskimo archaeology of Julianehaab District. Meddelelser om Grønland 118, 141 pp.

Raahauge, K., Lund Jensen, E. \& Grønnow, B. 2005: I konebådens kølvand. Grønlandsposten (20 January).

Rasch, M. 2000: Holocene relative sea-level changes in Disko Bugt, West Greenland. Journal of Coastal Research 16, 306-315.

Rasch, M., Holm Jakobsen, B. \& Nielsen, N. 1997: Geomorphology and sedimentary record of three cuspate forelands as indicators of late Holocene relative sea-level changes, Disko, West Greenland. Danish Journal of Geography 97, 33-46. 
Rasch, M. \& Jensen, J. F. 1997: Ancient Eskimo dwelling sites and Holocene relative sea-level changes in southern Disko Bugt, central West Greenland. Polar Research 16, 101-115.

Reimer, P. J., Baillie, M. G. L., Bard, E., Bayliss, A., Beck, J. W., Bertrand, C. J. H., Blackwell, P. G., Buck, C. E., Burr, G. S., Cutler, K. B., Damon, P. E., Edwards, R. L., Fairbanks, R. G., Friedrich, M., Guilderson, T. G., Hogg, A. G., Hughen, K. A., Kromer, B., McCormac, G., Manning, S., Bronk Ramsey, C., Reimer, R. W., Remmele, S., Southon, J. R., Stuiver, M., Talamo, S., Taylor, F. W., van der Plicht, J. \& Weyhenmeyer, C. E. 2004: IntCal04 terrestrial radiocarbon age calibration, $0-26$ cal kyr BP. Radiocarbon 46 , $1029-1058$.

Röhl, U. \& Abrams, L. J. 2000: High-resolution, downhole, and nondestructive core measurements from site 999 and 1001 in the Caribbean Sea: Application to the late Paleocene thermal maximum 1. In Leckie, R. M., Sigurdsson, H., Acton, G. D. \& Draper, G. (eds.): Proceedings of the Ocean Drilling Program, Scientific
Results 165, 191-203. College Station, TX (Ocean Drilling Program).

Sparrenbom, C. J., Bennike, O., Björck, S. \& Lambeck, K. 2006: Relative sea-level changes since 15,000 cal. yrs BP in the

Nanortalik area, southern Greenland. Journal of Quaternary Science 21, 29-48.

Tarasov, L. \& Peltier, W. R. 2002: Greenland glacial history and local geodynamic consequences. Geophysical Journal International 150, $198-229$.

Weidick, A., Kelly, M. \& Bennike, O. 2004: Late Quaternary development of the southern sector of the Greenland Ice Sheet, with particular reference to the Qassimiut lobe. Boreas 33, 284299.

Zwartz, D., Tregoning, P., Lambeck, K., Johnston, P. \& Stone, J. 1999: Estimates of present-day glacial rebound in the Lambert Glacier region, Antarctica. Geophysical Research Letters 26, 1461 1464. 